\title{
Load capacity of caisson anchors exposed to seabed trenching
}

2

3

4

5

6

7

8

\author{
X. Feng ${ }^{1}$, S. Gourvenec ${ }^{2}$, D. J. White ${ }^{3}$
}

Manuscript accepted for publication in Ocean Engineering on 7 September 2018

\section{${ }^{1}$ Xiaowei FENG (corresponding author)}

Centre for Offshore Foundation Systems - M053

University of Western Australia

35 Stirling Highway, Crawley

Perth, WA 6009

Australia

Tel: +61 864882473

Fax: +61 864881044

Email: xiaowei.feng@uwa.edu.au

\section{Susan GOURVENEC}

Faculty of Engineering and Physical Sciences

University of Southampton

Tel: +44 (0)23 80599139

Email: susan.gourvenec@southampton.ac.uk

\section{${ }^{3}$ David J. WHITE}

Faculty of Engineering and Physical Sciences

University of Southampton

Tel: +44 (0)23 80596859

Email: david.white@soton.ac.uk

No. of words: 6286 (without abstract and references)

No. of tables: 1

No. of figures: 17 


\section{Load capacity of caisson anchors exposed to seabed trenching}

\section{ABSTRACT}

Floating structures are often secured in position with a taut mooring system and suction caissons. Large seabed trenches have been observed adjacent to some suction caisson anchors with taut-line mooring systems. The trenches may jeopardise the geotechnical capacity of the caissons and in turn the stationkeeping of the floating structures. Finite-element method is employed to examine the geotechnical capacity of suction caissons in a trenching seabed. The results show that the reduction in the geotechnical capacity becomes more significant with increasing trench width due to the loss of soil support and a change in failure mechanism as the caisson rotates into the trench. For a given trench width, the reduction in capacity becomes more significant as the load inclination angle to the horizontal decreases. However, the shape of the normalised failure envelopes for combined vertical and horizontal load is insensitive to trench width. A strategy to design for inevitable trenching by moving the padeye shallower to reduce the depth of trench formation is not straightforward. The gain from a shallower trench may often be outweighed by the reduction in capacity from rotation of the caisson at failure for loading angles typical of taut moorings.

\section{KEYWORDS}

57 caisson; trenching; failure; numerical modelling; offshore engineering; 


\section{INTRODUCTION}

60

61

Suction anchors coupled with catenary or taut-line mooring systems are widely adopted to moor floating facilities for offshore oil and gas developments and are a potential anchoring solution for floating renewable energy facilities (Andersen et al., 2005; Tjelta, 2015; Statoil, 2015; Oh et al., 2018). A catenary mooring is characterised by the mooring line resting on the seabed before the anchor point, while a taut line mooring reaches the anchor point at an angle, without a grounded section (Figure 1). A catenary mooring forms a catenary shape in the water column from the floating facility to the seabed and an inverse catenary from the seabed to the anchor chain attachment point on the anchor, the padeye. Catenary moorings are typically formed from chain (or a combination of chain and synthetic rope), while taut moorings are generally formed from synthetic rope, which is much lighter than chain (but with short sections of chain at either end). A taut line mooring will usually make an angle of $30-45^{\circ}$ to the horizontal between the floating facility and the padeye, with little change in the angle over the length of the line, as a result of the low mass per unit length of the anchor line. Semi-taut moorings lie between the catenary and taut concepts. Taut and semi-taut line moorings are attractive in deep water environments to reduce the footprint of the mooring spread and improve the motion characteristics of the floating system, but recent evidence suggests that the cyclic motion of the anchor line at the mudline and through the seabed can contribute to the development of seabed trenches.

Large trenches have been observed as a result of anchor chain-soil interaction on multiple offshore projects, and one of the first cases has been reported in the public domain (Bhattacharjee et al., 2014). These trenches formed to the depth of the padeye and extended in front of the caisson by more than twice the distance to the chain exit point at the original mudline, as illustrated schematically in Figure 2. Other instances of seabed trenching have since been shared in the public domain indicating the extent of the phenomenon (Sassi et al., 2017; 
Colliat et al., 2018; O'Neill et al., 2018). The formation of the trenches is controlled by mechanism similar to the trenching of steel catenary risers (Bridge and Howells, 2007). These include (i) a 'softening' mechanism in which soil is disturbed and remoulded by the chain pretension and cyclic motions; (ii) a 'transport' mechanism causing suspension and erosion of the softened soil; and (iii) a 'stability' mechanism that enables the trench to remain open and stable once formed, if there is an adequately high normalised shear strength (i.e. the ratio $\mathrm{s}_{\mathrm{u}} / \sigma_{\mathrm{v}}^{\prime}$ ).

Soil loss in the vicinity of a suction caisson has the potential to significantly reduce the geotechnical capacity due to loss of support from the seabed. Optimised design of the chain attachment point generally leads to translation of the caisson under the design load, but any trenching effect may lead to caisson rotation, and a reduced capacity. To date, there is little information available on the effect of seabed mooring line trenching on the holding capacity of suction caissons for floating facilities.

Various analytical, numerical and experimental studies have been carried out to investigate the holding capacity of suction caissons in intact seabeds, with and without a tension gap forming on the active side of a caisson during rotation. The focus of much early work was the vertical pullout capacity of suction caissons (Steensen-Bach, 1992; Andersen et al., 1993; Watson and Randolph, 1997). A limiting equilibrium model for undrained inclined pullout capacity of suction anchors was presented by Andersen and Jostad (1999). Upper bound solutions for suction caisson capacity under undrained inclined load were established (Randolph and House, 2002; Aubeny et al., 2003) by adding new failure mechanisms to those introduced for the undrained capacity of laterally loaded piles (Murff and Hamilton, 1993). The response of suction caissons subjected to combined vertical and horizontal loading was investigated through interaction diagrams developed with finite element analyses (Zdravkovic et al., 2001; Senders and Kay, 2002; Supachawarote et al., 2004; 2005; Saviano and Pisanò, 2017). Results from an industry sponsored project on a range of geotechnical design aspects of suction caissons in 
109 (intact) soft clay seabeds were presented by Andersen et al. (2005). Experimental studies on inclined load capacity of suction caissons, in both small scale and prototype scale models, have

111 been reported by various researchers (Andersen et al., 1993; Watson et al., 2000; Clukey et al., 112 2003). From this previous work, procedures for analysing suction caisson capacity are well 113 established for intact seabed conditions. Disturbed seabed conditions, such as after scour or 114 sediment erosion, have also been considered in calculating the lateral resistance of the piles 115 (Achmus et al., 2010; Qi et al., 2016). A project-specific numerical study of trenching effects around a suction caisson was presented by Alderlieste et al. (2016), but as yet no generalised guidance is available. The viability of the finite element method to determine the load capacity of suction caissons exposed to a trench was demonstrated in Sassi et al. (2018).

This paper examines the effect of seabed mooring line trenching on the undrained geotechnical capacity of suction caisson anchors. The inclined capacities of suction caissons are obtained

121 from finite element (FE) analysis under various trenched seabed conditions. A normally122 consolidated fine-grained soil with linearly increasing undrained shear strength with depth is considered, as relevant to deep water seabed conditions where taut-line moorings for floating facilities are most prevalent. The inclined pullout capacity of a suction caisson in a trenched seabed is compared to that for an intact seabed, considering variations in trench width, load inclination angle and interface condition between the caisson and the seabed to represent

127 drainage that would occur following trench formation. Designing for inevitable trenching by adjusting the initial padeye location is also investigated.

The study provides insights into governing mechanisms of failure of suction caisson anchors

130 with taut moorings in a trenched seabed through systematic study of trench geometry, loading angle and drainage conditions following trench formation. The effect of out-of-plane motion of

132 the mooring line is not considered in the current work. Results are presented for a single caisson aspect ratio and soil strength profile, representative of deepwater seabed conditions and 
caissons that are most relevant to the boundary value problem under consideration. The adopted conditions are based on the first published case study of anchor line trenching.

\section{FINITE ELEMENT MODEL}

All the finite element analyses presented from this study were carried out using the commercially available software package ABAQUS 6.14. The general approach is consistent with previous studies that have been used to define yield envelopes for caisson capacity that are widely used in practice (Zdravkovic et al., 2001; Supachawarote et al., 2004; Aubeny et al., 2003), and have been adopted in industry codes and guidelines (ISO, 2016). In this way, the results for the no-trenched case represent a baseline consistent with current practice, and the trenching is superimposed on this to identify the effect on capacity.

\subsection{Geometry and meshes}

The length-to-diameter aspect ratio of the modelled caisson is identical to that presented in the published field case study (Bhattacharjee et al., 2014), and reflects the geometry of field anchors at deep water sites where the seabed is susceptible to mooring line trenching (Arslan et al., 2015; Alderlieste et al., 2016). The suction caisson considered has a length-to-diameter ratio of $\mathrm{L} / \mathrm{D}=3.11$, from a diameter of $4.5 \mathrm{~m}$ and length of $14.0 \mathrm{~m}$. The seabed trench was taken to reach the padeye depth, $\mathrm{z}_{\mathrm{p}}$ (as observed in the field case) and the width of the trench was varied according to a prescribed width-to-diameter ratio, w/D $=0.25,0.5,0.75,1.0$ and 1.25 . The extent of the trench perpendicular to the caisson was assumed to be infinite. This is a reasonable approach since the zone of the failure mechanism in front of the caisson does not extend as far as the (finite) limit of observed seabed trenches. The problem definition is shown schematically in Figure 3.

A typical three-dimensional finite element mesh is shown in Figure 4 for the analysis of a suction caisson embedded in a seabed with a trench of width w/D $=0.75$. Only half of the model 
158

159

160

161

162

163

164

165

166

$\frac{\mathrm{h}_{\mathrm{uf}} \mathrm{k}}{\mathrm{s}_{\mathrm{u}, \mathrm{tip}}}=0.2$
167

168

169

170

171

172

173

174

175

176

177

is used since symmetry exists in the plane of loading. Horizontal displacement normal to the plane of symmetry (the front face in Figure 4) is prevented throughout of the analysis. The meshes extended 3L from the edges of the caisson and 3L beneath the caisson tip level, with horizontally constrained nodes at the sides, and fully constrained nodes at the base. The boundaries were shown to be sufficiently remote so that the failure mechanism was not affected. A region of very thin elements (approximately 1\%D) was employed around the caisson perimeter to ensure accurate representation of shearing along the caisson shaft (Supachawarote et al., 2004) whereas the required element size, $h_{u f}$, adjacent to the caisson base is determined as proposed by Hu and Randolph (2002)

where $\mathrm{k}$ is the gradient of the soil undrained shear strength and $\mathrm{s}_{\mathrm{u}, \mathrm{tip}}$ is the soil shear strength at the caisson base level.

First order 8-node fully integrated hybrid continuum elements were used for the soil domain (refer to $\mathrm{C} 3 \mathrm{D} 8 \mathrm{H}$ in the ABAQUS element library). Hybrid elements are recommended for modelling the response of incompressible and near-incompressible materials (Brezzi and Fortin, 2012), such as soil under undrained conditions.

\subsection{Material properties and interface conditions}

The analyses were intended to replicate the undrained response of a soft normally consolidated soil with an undrained shear strength increasing proportionally with depth, $\mathrm{z}$ according to $\mathrm{s}_{\mathrm{u}}=$ kz. Normally consolidated seabeds are prevalent in deepwater locations that are most desirable for taut mooring applications. The gradient of the soil undrained shear strength was adopted as $\mathrm{k}=2 \mathrm{kPa} / \mathrm{m}$ in this study. Although this is a higher gradient than found in the Gulf of Mexico (Quirós et al., 2000), it is in line with other regions where suction caissons are used (Colliat et 
al., 2010; Erbrich and Hefer, 2002). The soil was modelled as linear elastic, perfectly plastic

181

182

183

184

185

186

187

188

189

190

191

192

193

194

195

obeying a Tresca failure criterion. The elastic properties were defined by undrained Young's modulus $\mathrm{E}=1000 \mathrm{~s}_{\mathrm{u}}$ and Poisson's ratio of $v=0.49$ (to avoid numerical difficulties associated with the constant-volume response of soil under undrained conditions). This gives a relatively high rigidity index $\mathrm{G} / \mathrm{s}_{\mathrm{u}}$ of 336 , where $\mathrm{G}$ is the shear modulus of the soil. The submerged unit weight, $\gamma^{\prime}$, of the soil was taken as $3 \mathrm{kN} / \mathrm{m}^{3}$ in this study, representative of seabed deposits where trenching has been observed (Ehlers et al., 2005; Colliat et al., 2010). The normalised shear strength of $\mathrm{s}_{\mathrm{u}} / \sigma_{\mathrm{v}}{ }_{\mathrm{v}}=\mathrm{k} / \gamma^{\prime}=0.67$ exceeds the analytical plane strain solution of 0.5 for an unsupported vertical cut (Gibson and Morgenstern, 1962). The origin of the anomalously high value of $s_{u} / \sigma^{\prime}{ }_{v}$ might be a product of bioturbation and geochemical transformation in sediments, or other features of the mineralogy and composition (Ehlers et al., 2005; Kuo and Bolton, 2013). It is these conditions, where the trench can stay open as an unsupported vertical cut without undrained collapse, that are relevant to mooring line trenching issues.

The caisson was represented as a rigid solid plug to represent an unvented cap condition, and the motion of the caisson was controlled by a reference node along the midline of the caisson at a depth of $\mathrm{z}_{\mathrm{cl}}$, representing the intersection of the loading vector of the mooring chain at the padeye with the centreline of the caisson (Figure 3), which governs caisson response to inclined loading (Randolph \& House., 2002).

$\mathrm{z}_{\mathrm{cL}}=\mathrm{z}_{\mathrm{p}}+\frac{\mathrm{D}}{2} \tan \theta$

where $\theta$ is the load inclination angle to the horizontal.

In the analyses, all caisson loads and displacements were applied or recovered at the reference point. The submerged unit weight of the caisson foundation was assumed to be identical to that of the soil. Therefore, the vertical capacity derived from the FE analyses was the net capacity neglecting the submerged self-weight of the caisson. 
The interface between the shaft of the caisson and the soil was modelled in two ways. Firstly, the caisson was modelled as fully bonded to the soil, allowing unlimited tension to be mobilised, representing a case of suction at the interface. Secondly, a zero tension interface was modelled, to allow the possibility of loss of suction forming at the interface. Gap formation is a design concern, since the presence of a seabed trench may accelerate the dissipation of the negative excess pore pressure around the caisson, preventing suction being maintained on the active face and therefore eliminating any interface tension.

The normal behaviour of the zero-tension interface was modelled by 'hard' contact with no tensile stress transmitted, and the tangential behaviour was represented by the Coulomb frictional contact with coefficient of friction of 1.0. The underside of the caisson was fully bonded to the soil with no detachment allowed, representing the 'soil-soil' interface between the soil plug and the underlying soil.

\subsection{Analysis procedure}

The caisson was pre-embedded without considering the effect of installation. The geostatic stresses of the soil were initially established for the intact seabed condition, with a set of elements at the location where the trench would subsequently be formed. The development of the seabed trench was simulated by deactivating the predefined elements in the trenched zone with the model change function in ABAQUS. For the particular case of the instant of trench development, the out-of-plane displacement constraint over the trenched zone at the plane of symmetry in the model for intact seabed ( $/ \mathrm{D}=0$ ) was released to simulate an infinitesimally narrow trench. Following trench development, an external load was applied to the suction caisson at the reference node by either imposing a displacement or a directly applied force to bring the caisson to failure and the load capacity was determined. 


\subsection{Load path}

227 For cases when the caisson body was free to rotate, a concentrated force or a displacement was

228 specified at the reference point along the direction of the prescribed load inclination. The

229 maximum capacity of the caissons was determined by prescribing translation without rotation, 230 in practice achieved by moment equilibrium from the optimal combination of padeye depth and 231 loading angle for the particular caisson geometry and undrained shear strength profile.

\section{RESULTS}

233

The finite element model was validated by considering the pure vertical pullout capacity and translational capacity of the suction caisson embedded in an intact seabed, i.e. w/D $=0$. Subsequently, the load capacity of the suction caisson in trenched seabeds is presented for the padeye located at the designated depth of $9 \mathrm{~m}$ (Bhattacharjee et al., 2014). Finally, the influence of padeye offset is discussed to examine the effect of the trench depth on capacity.

\subsection{Caisson load response verification-Intact seabed}

\section{Vertical pullout capacity}

The undrained vertical pullout capacity of a caisson in an intact seabed consists of the shearing resistance along the caisson shaft and the reverse end bearing resistance at tip level. For the conditions modelled, shaft resistance can be deduced from the product of the shaft surface area and the average shear strength over the embedded depth modified by a soil-structure interface factor. The base resistance was estimated by subtracting the theoretical shaft resistance from the total load obtained from the vertical pullout analyses. The end bearing factor $\mathrm{N}_{\mathrm{c}}$ can be calculated according to 


$$
\mathrm{N}_{\mathrm{c}}=\left(\mathrm{V}_{\mathrm{ui}}-\pi \mathrm{D} \int_{0}^{\mathrm{L}} \alpha \mathrm{s}_{\mathrm{u}} \mathrm{dz}\right) / \mathrm{As}_{\mathrm{u}, \mathrm{tip}}
$$

247 Where

$248 \mathrm{~V}_{\mathrm{ui}}=$ ultimate pullout force at failure (taken as the force at a displacement of 0.1D at a plastic

249 plateau)

250 A $=$ cross sectional, bearing, area of the caisson

$251 \alpha=$ interface friction ratio, taken as 1 for full caisson-soil adhesion.

252 The computed value of $\mathrm{N}_{\mathrm{c}}$ is approximately 10.9, compared with 10.5 for length-to-diameter 253 L/D greater than 3 based on two-dimensional axisymmetric finite-element analyses reported by

254 Aubeny et al. (2003).

\section{Horizontal translation capacity}

The translational capacity of a suction caisson derives from the shearing across the base at tip level, potentially a deep flow-around mechanism above toe level, and a wedge-type failure of the soil at shallow depths (Figure 5). The soil resistance mobilised by the soil wedges is governed by the gapping conditions, which are relevant to the caisson-soil interface properties. Under the zero-tension interface (ZTI) condition, a gap may form on the active side of the caisson. The soil resistance for such a one-sided wedge mechanism is only due to the shear strength and weight of the passive wedge in front of the caisson. For the case of an unlimited tension interface (UTI) where a gap cannot form, the soil resistance due to the shear strength of 264 the passive and active wedges is equal for a two-sided mechanism, but the resistance associated 265 with the weight of the wedges cancels out.

266 The lateral capacity of the caisson, excluding base shearing, may be assessed using the profiles 267 of lateral resistance factor, $\mathrm{N}_{\mathrm{p}}$, derived from the plasticity solution for a one-sided mechanism 
proposed by Murff and Hamilton (1993). An approximate fit of Equation (4) based on the

analytical solution was suggested for the variations of $\mathrm{N}_{\mathrm{p}}$ with depth (Figure 5).

$\mathrm{N}_{\mathrm{p}}(\mathrm{z})=\mathrm{N}_{1}-\mathrm{N}_{2} \mathrm{e}^{-\xi z / \mathrm{D}}$

270 where $\mathrm{N}_{1}$ is the limiting bearing factor at depth, varying with interface friction from 9.14 for a

271 smooth caisson, to 11.94 for a fully rough caisson (Martin and Randolph, 2006). $\mathrm{N}_{2}$ is selected

272 such that $\left(\mathrm{N}_{1}-\mathrm{N}_{2}\right)$ is the capacity factor at the intercept at the soil surface, being 2.82 and 2 for

273 a rough and smooth caisson, respectively (Aubeny et al., 2003). The decay factor, $\xi$,

274 characterises the effect of soil strength profile, expressed as

$\xi=0.25+0.05 \operatorname{Min}\left(6, \mathrm{~s}_{\mathrm{um}} / \mathrm{kD}\right)$

275 where $s_{u m}$ is the soil undrained strength at mudline and $\mathrm{k}$ is the strength gradient.

276 Assuming a two-sided mechanism with no gap for full caisson-soil adhesion, the value of $\mathrm{N}_{\mathrm{p}}$ 277 needs to be doubled, subject to the restriction that $\mathrm{N}_{\mathrm{p}}$ does not exceed the limiting value at 278 depth, $\mathrm{N}_{1}$ (Aubeny et al., 2003).

279 The normalised horizontal capacity factor for a translating caisson $\mathrm{N}_{\mathrm{h}}$ is defined as

$\mathrm{N}_{\mathrm{h}}=\left(\mathrm{H}_{\mathrm{ui}}-\mathrm{As}_{\mathrm{u}, \mathrm{tip}}\right) / \mathrm{LDs}_{\mathrm{u}, \text { avg }}$

280 Where $\mathrm{H}_{\mathrm{ui}}$ is the ultimate horizontal capacity for a translational caisson and $\mathrm{s}_{\mathrm{u}, \text { avg }}$ is the average 281 soil shear strength over the depth of caisson embedment. The value of $\mathrm{N}_{\mathrm{h}}$ derived from the FE 282 analysis is 10.9 for UTI, $4.4 \%$ lower than the upper bound solution of 11.4 , whereas the FE 283 result of $\mathrm{N}_{\mathrm{h}}$ is 7.5 for ZTI condition, 8.7\% higher than the analytical solution of 6.9 using the $284 \mathrm{~N}_{\mathrm{p}}$ profile provided in Equation (4). 


\subsection{Effect of trench on vertical pullout and translational capacity}

The reduction ratio of pure pullout, $\mathrm{V}_{\mathrm{u}}$, and translational load capacity, $\mathrm{H}_{\mathrm{u}}$, in the trenched seabed compared to the intact seabed is shown in Figure 6 for UTI, (i.e. full suction maintained) and ZTI (i.e. no suction permitted behind the caisson due to possible rapid drainage to the trench) cases, as a function of trench width. The trench is assumed to develop to the level of the padeye, located at $0.64 \mathrm{~L}$, consistent with the optimal position for a taut-line system in a

normally consolidated intact seabed. The changes in pure vertical and horizontal capacities are

not intended to represent or inform on potential uniaxial failure mechanisms in the field but to provide insight into effects of trenching on these idealised cases as a basis for considering inclined loading.

Figure 6 shows that both vertical and translational capacities reduce with increasing trench width and the loss of suction behind the caisson, more significantly for translational capacity. The undrained vertical pullout capacity of caissons in a trenched seabed consists of the shearing resistance along the caisson shaft and the reverse end bearing resistance at tip level, identical to in an intact seabed. The shaft resistance during pullout decreased in the trenched seabed due to the reduced contact area between the caisson and the seabed. The end resistance factor considering the trenched soil can be predicted by Equation 7, accounting for the shaft area affected by the trench, as

$\mathrm{N}_{\mathrm{c}}=\left(\mathrm{V}_{\mathrm{u}}-\pi \mathrm{D} \int_{0}^{\mathrm{L}} \alpha \mathrm{s}_{\mathrm{u}} \mathrm{dz}+\operatorname{Dsin}^{-1} \int_{0}^{\mathrm{z}_{\mathrm{p}}} \alpha \mathrm{s}_{\mathrm{u}} \mathrm{dz}\right) / \mathrm{As}_{\mathrm{u}, \mathrm{tip}}$

The end resistance factor $\mathrm{N}_{\mathrm{c}}$ of the caissons in a trenched seabed, presented in Figure 7 , is practically identical with that in the intact seabed irrespective of the interface condition, indicating that the effect of the trench on end bearing resistance is minimal despite the reduced overburden. Therefore, the reduction of the pullout capacity is induced by loss of caisson surface area in contact with soil. For the case where suction is lost on the caisson-soil interface, 
the reduction in vertical capacity becomes more significant as the trench width increases, since the caissons rotates more significantly into the trench at the stage of trench development, leading to more loss of contact and therefore shaft resistance in the following uplift.

The reduction in translational capacity for a trenched seabed shown in Figure 6 and the calculated normalised horizontal capacity factor $\mathrm{N}_{\mathrm{h}}$, from Equation 6, is plotted in Figure 7. The reduction in the translational capacity is caused by the loss of soil in the trenched zone and the change in the soil flow mechanism around the caisson. The soil flow mechanisms for the UTI and ZTI are illustrated in Figure 8 and Figure 9, respectively. A step fall in $\mathrm{H}_{\mathrm{u}}$ for the UTI $(\sim 10 \%)$ and ZTI ( 15\%) is evident for w/D $\rightarrow$ 0, i.e. for an infinitesimally narrow trench even though the same volume of soil is present around the caisson. This immediate reduction in capacity is because any trench removes the potential for tensile resistance across the front of 319 the caisson, with this wound weakening the soil support. Figure 8a and b show the abrupt 320 change in the soil flow mechanism on the front side of the caisson with UTI for an intact seabed 321 and $\mathrm{w} / \mathrm{D} \rightarrow 0$. The scenario of $\mathrm{w} / \mathrm{D} \rightarrow 0$ is not intended to represent a physical reality, but is 322 examined to demonstrate the significant effect of the change of the soil failure mechanism, as 323 shown in Fig.8b, and explain the step change (rather than smooth transition) in the load capacity 324 of the caisson when the seabed transitions from intact into trenched conditions.

325 In the absence of the active soil wedge, Figure 9a and b demonstrate a similar immediate 326 transition in mechanism at the passive side for caissons with ZTI. As the trench widens to w/D $327=1, \mathrm{H}_{\mathrm{u}}$ reduces respectively to $\sim 70 \%$ and $\sim 53 \%$ of the untrenched value for the UTI and the 328 ZTI, as the volume of soil in the failure mechanism progressively reduces.

329 For the zero tension interface, the gap on the active side extends to the caisson tip and the soil 330 wedge does not mobilize owing to the soil detachment. The difference in $\mathrm{N}_{\mathrm{h}}$ between ZTI and 331 UTI conditions is essentially independent of trench width (see Table 1), since it is governed by 
the contribution of the soil resistance mobilised on the active side of the caisson, away from the trench. The discrepancy accounts for 31\% (<50\%) of the untrenched value for UTI due to the contribution of the soil weight on the active side.

The case of an infinitesimally narrow trench is only of theoretical interest but shows that the trench affects $\mathrm{H}_{\mathrm{u}}$ via two distinct effects - (i) elimination of tensile resistance ahead of the caisson, and (ii) a reduction in the overall volume of deforming soil.

\subsection{Inclined load capacity of caissons - Effect of trench width}

The results above have shown that the presence of a seabed trench reduces the pullout and translational capacity of suction caissons due to the absence of resistance from the soil in the trenched zone and loss of suction on the caisson/soil interface. In this section, the effect of the trench on the inclined load resistance, $\mathrm{F}_{\mathrm{u}}$, is presented, demonstrating the additional reduction in capacity due to the possible rotation of the suction caisson in a trenched seabed, as opposed to a pure translational mechanism that the caisson would have been designed for considering an intact seabed.

Results are presented in terms of a reduction factor, defined as the ratio of the geotechnical capacity of the caisson in the trenched seabed $F_{u}$ to that in the intact seabed $F_{u i}$. All curves except those for $\theta=90^{\circ}$ in Figure 10 converge to $F_{u} / F_{u i}<1$ for trench width w/D $\rightarrow 0$. This is because an infinitesimally thin trench is responsible for eliminating tension across the front of the caisson - as shown in Figure 6 for pure horizontal loading $\left(\theta=0^{\circ}\right)$.

Figure 10 illustrates the components of reduction in capacity separated by (i) loss of suction behind and soil support in front of the caisson, and (ii) rotation of the caisson. Effect (i) is derived by constraining rotation while modelling the trench depth at the level of the padeye corresponding to the optimal loading point for each chain angle for an intact seabed (Figure 10a). The load-capacities shown in Figure 10b represent caissons embedded in the trenched 
seabed with rotation permitted and the load applied at the depth where no rotation would occur for an intact seabed. The reduction in capacity becomes increasingly significant as the trench width increases and for load inclination angles of $\theta<60^{\circ}$, and is more significant for the case of loss of suction on the caisson/soil interface. The greater reduction in capacity due to rotation arises from effect (ii), because the depth of intersection of the loading vector at the caisson centreline that causes pure translation, $\mathrm{z}_{\mathrm{o}}$, becomes deeper with increasing trench width, as shown in Figure 11. Therefore, the optimal padeye position for the intact seabed condition is not optimal for the trenched seabed. Instead, it is too shallow and induces forward rotation of the caisson. For the case of zero-tension interface, the soil resistance due to the active wedge is absent, and the moment attributed to the passive soil wedge must equilibrate that associated with the tip sliding to achieve the translating mechanism. Therefore, the optimal load intersection with the centreline becomes deeper than that for the case of UTI. Additional analyses with $\mathrm{k}$ in the range of $1.6-2.4 \mathrm{kPa} / \mathrm{m}$ confirm that the values of $\mathrm{z}_{\mathrm{o}}$ presented in Figure 11 are insensitive to the adopted gradient of the undrained shear strength $\mathrm{k}$, showing a variation within $2 \%$ for given seabed and interface conditions.

The reduction in the capacity caused by free rotation compared with the translating caisson is

372 minimal for loading with a significant vertical component, $\theta>60^{\circ}$. An example of the 373 dependence of capacity on loading angle $\theta$ is shown in Figure 12 as a function of the depth to 374 the load intersection point at the centreline of a caisson for the case of UTI, and embedded in 375 a trenched seabed with $w / D=0.25$. Figure 12 indicates that for the load inclination angle $\theta<\sim$ $37660^{\circ}$ to the horizontal, the capacity is highly sensitive to the intersection of the loading vector 377 with the centreline as the transition in mechanism from translational to rotational is abrupt. For 378 load inclination angles greater than $60^{\circ}$ to the horizontal, where the caisson failure is governed 379 by the vertical pullout, the capacity is only marginally reduced over a relatively wide range of 380 load attachment depths. 
The capacity of the suction caissons for any given load inclination angle can be determined from a $\mathrm{V}-\mathrm{H}$ interaction diagram. The $\mathrm{V}-\mathrm{H}$ capacity for caissons in a trenched seabed is presented in Figure 13a and b with respect to that in an intact seabed for UTI and ZTI, respectively. The dotted lines show the capacity for caissons permitted to rotate (as would occur in the field in the presence of trenching), with the load applied at the optimal attachment point for the intact seabed. The solid lines are the failure envelopes for the translating caissons, shown to highlight the separate effects of (i) loss of soil support in front of the caisson and (ii) the change of failure mechanism from translation to rotation. The capacity under inclined loading reduces with increasing trench width, w/D and for loading angles dominated by a horizontal component. For typical taut-line mooring angles, $30^{\circ} \leq \theta \leq 45^{\circ}$ to the horizontal, a trench as wide as the caisson diameter causes a reduction in capacity to $60 \%-75 \%$ of the optimal capacity in an intact seabed for the conditions modelled. If suction is lost on the active side of the caisson, the capacity for w/D $=1.0$ would reduce more significantly to $36 \%-42 \%$ of the optimal value 394 for untrenched seabed.

395 The normalised V-H failure envelopes are plotted in Figure 14a for unlimited tension interface conditions (UTI), revealing that the shape of the failure envelope is insensitive of the trench 397 width and the mode of caisson motion. A general ellipse defined for intact seabed and aspect 398 ratio of $1.5<\mathrm{L} / \mathrm{D}<5.0$ can be used to describe the failure envelopes (Supachawarote et al., 399 2004):

$$
\left(\frac{\mathrm{H}}{\mathrm{H}_{\mathrm{u}}}\right)^{0.5+\mathrm{L} / \mathrm{D}}+\left(\frac{\mathrm{V}}{\mathrm{V}_{\mathrm{u}}}\right)^{4.5-\mathrm{L} / 3 \mathrm{D}}=1
$$

400 For the case of ZTI, the shape of the failure envelope is independent of the trench width, but is 401 (slightly) affected by whether the caisson is constrained to translate or free to rotate for load 402 inclination angle $\theta<45^{\circ}$. 


\subsection{Padeye offset for optimal capacity in a trenched seabed}

$$
\mathrm{P}_{\mathrm{p}} \mathrm{L}_{\mathrm{p}}+\mathrm{P}_{\text {tip }} \mathrm{L}_{\mathrm{t}}=\mathrm{P}_{\mathrm{a}} \mathrm{L}_{\mathrm{a}}
$$
padeye is discussed.

The location of the padeye determines the maximum trench depth as well as the capacity and mode of failure of the caisson. It is therefore worth consideration if the location of the padeye can be optimized assuming trench formation down to padeye depth is inevitable. There is a trade-off between locating the padeye at a shallower than optimal depth (for the intact seabed case), thereby accepting a rotational failure mode, in order to reduce the depth to which the trench develops. In this section, the effect of trench depth or adjustment of the location of the

Figure 11 compares the locations of the optimal load intersection point at the centreline of the caisson for various padeye positions which change from the mid-height of the caisson embedment, i.e. $\mathrm{z}_{\mathrm{p}} / \mathrm{L}=0.5$, to the depth to optimal load intersection with the centreline for an intact seabed, i.e. $\mathrm{z}_{\mathrm{p}} / \mathrm{L}=0.7$ for UTI and 0.73 for ZTI. The depth to the optimal load intersection with the caisson centreline increases as the trench width increases regardless of the interface properties. For given trench width, the reduction of the depth to the optimal load intersection with the centreline is minimal for caissons with UTI. The reason is that the soil reaction force $\mathrm{P}_{\mathrm{a}}$ against the active side of the caisson and the sliding resistance $\mathrm{P}_{\text {tip }}$ at the caisson tip are virtually unaffected by the presence of the seabed trench, whereas the passive soil reaction force $\mathrm{P}_{\mathrm{p}}$ increases for a shallower trench depth, but the corresponding moment arm decreases so that the position of the optimal load intersection point at caisson centreline (point O) shifts slightly to achieve the moment equilibrium for a translating mechanism (Figure 15).

where $\mathrm{P}_{\mathrm{p}}, \mathrm{P}_{\text {tip }}$ and $\mathrm{P}_{\mathrm{a}}$ respectively are the forces acting on the passive side, tip and active side of the caisson, with $L_{p}, L_{t}$ and $L_{a}$ being the corresponding moment arm with respect to O. Even though the reduction of the depth to the optimal load intersection with the centreline is more 
significant for caissons with zero-tension interface than that for UTI (Figure 11), it is still considerably smaller compared with the padeye offset, leading to forward rotation of the caisson for the loading direction at the padeye. Therefore, the gain in the geotechnical capacity of the caisson from a shallower trench might be outweighed by the reduction owing to caisson rotation.

The load capacity of caissons in seabeds with various depths of mooring line-induced trenches is presented in Figure 16, where the trench depth varies according to the prescribed load intersection point at the caisson centreline, $\mathrm{z}_{\mathrm{CL}}$ and load inclination angle, $\theta$. Moving the padeye to a shallower depth does not necessarily lead to a higher geotechnical capacity for load inclination angles less than or equal to $45^{\circ}$ to the horizontal, most relevant to taut or semi-taut mooring systems. With a full tension interface, i.e. suction maintained on the passive side of the caisson, the geotechnical capacity for a caisson with loading angle $\theta=30^{\circ}$ and trench width $\mathrm{w} / \mathrm{D}=1.0$ reduced by $7 \%$ as the depth of the padeye decreased from $0.68 \mathrm{~L}$ to $0.61 \mathrm{~L}$. If suction is lost on the active side of the caisson, the load capacity for $\theta=45^{\circ}$ can reduce $10 \%$ with the trench depth decreased from $0.68 \mathrm{~L}$ to $0.54 \mathrm{~L}$. This is because the geotechnical capacity of the caisson is very sensitive to the position of the load intersection point at the centreline for small load inclination angles. For load inclination angles exceeding $75^{\circ}$ to the horizontal, vertical pullout dominates the failure and the reduction in the geotechnical capacity results from the loss of contact rather than the change in the failure mechanism of the caisson. The geotechnical capacity is lower for any trench width as the trench depth increases, as would be expected. The results presented in Figure 16c show that the capacity varies in approximate proportion to the trench width. 


\section{APPLICATION OF RESULTS TO CASE STUDY}

The results of this study indicate that when the trench geometry observed in front of the Serpentina suction caissons (Bhattacharjee et al. 2014) is considered in the present analysis, the holding capacity of any individual caisson is reduced by up to $65 \%$ for a trench as wide as the caisson diameter $(\mathrm{w} / \mathrm{D}=1)$, compared to the optimal capacity assuming an intact seabed and location of the padeye, $z_{p} / L=0.64$, to mobilize a translational failure mechanism (Figure 17).

Moving the padeye to a shallower position to reduce the trench depth would not have increased the holding capacity above the trenched capacity at the original padeye depth. This is because the gain from the reduced trench depth is exceeded by loss in capacity from transition to a rotational mechanism for these conditions.

The design capacity could be achieved by various combinations of increased caisson diameter and/or length and padeye location. One example is to maintain the original loading angle, caisson aspect ratio, and aim to achieve the design capacity indicated in Figure 17, which corresponds to pure translation in an intact seabed with the actual anchor dimensions. This capacity would require the caissons to be $7.14 \mathrm{~m}$ in diameter and $22.2 \mathrm{~m}$ in length with a padeye at mudline. This represents a significant increase in size compared to the original dimensions of $\mathrm{D}=4.5 \mathrm{~m}, \mathrm{~L}=14.0 \mathrm{~m}$ with depth to padeye $\mathrm{z}_{\mathrm{p}}=9 \mathrm{~m}$, to overcome the challenge of seabed trenching.

\section{CONCLUSIONS}

This paper has examined the load capacity of suction caisson anchors exposed to anchor line seabed trenching through finite-element analyses. The effect of a range of in-line load paths, interface conditions and trench configurations have been considered with reference to selected caisson geometry and soil profile, representative of field caissons and deep water seabed conditions, most relevant to the taut line mooring concept. This study has illustrated the 
significant effect of anchor line seabed trenching on caisson capacity for taut-line mooring systems and the variables that are significant to reduction in caisson capacity.

The analyses have revealed that:

- The reduction in vertical pull-out capacity is attributed to the loss of shaft resistance due to the trenched soil. For cases where suction is still mobilised at the caisson/soil interface away from the trenched area the undrained uplift capacity in the trenched seabed was generally $10 \%$ lower than compared with an intact seabed. In contrast, in cases where suction was lost at the caisson/soil interface due to the reduced drainage path length following trench formation, the vertical capacity for caissons reduces further as the trench width increases owing to greater loss of contact at the caisson/soil interface. The soil end resistance at caisson tip level was not significantly affected by the presence of the trench.

- Maximum horizontal capacity, i.e. mobilised under pure translation, was reduced by $40 \%$ and $\sim 70 \%$ as the trench width w/D reached unity for cases where suction at the caisson/soil interface was maintained or lost, respectively. The significant loss of capacity is attributed to a combination of the loss of soil support in the trenched zone and transition to a non-optimal rotational failure mechanism as the initial optimal depth of the padeye for an intact seabed becomes non-optimal in the presence of the trench, leading to rotation of the caisson.

- The reduction in inclined capacity of the suction caisson increased as the load angle to the horizontal decreased. The reduction in capacity was most significant for mooring line angles less than $60^{\circ}$ to the horizontal - noting that most taut line mooring systems have loading angles between $30^{\circ}$ and $45^{\circ}$. For loading angles $>75^{\circ}$, the failure mechanism is dominated by uplift.

- The shape of the normalised V-H failure envelopes was insensitive to the normalised trench width.

- The optimal depth to the load intersection point at the caisson centreline increased as the trench width increased and suction was lost on the active side. Improvement in geotechnical 
capacity by changing the padeye position to reduce trench depth was negligible because gains in capacity from a reduced trench depth were offset by reduction in capacity due to transition to a rotational mechanism.

Thus, in seabeds with a risk of anchor line trenching, anchor size must be increased in order to achieve the same design capacity. A range of combinations of caisson length and diameters along with loading angles could offer the target capacity, and drivers to narrow the selection of variables are likely to be project specific. In areas where trenching has been observed, a catenary mooring spread could be adopted and the larger footprint accommodated to minimize risk of trenching.

\section{ACKNOWLEDGEMENTS}

This work was supported by the ARC Industrial Transformation Research Hub for Offshore Floating Facilities which is funded by the Australian Research Council, Woodside Energy, Shell, Bureau Veritas and Lloyds Register (Grant No. IH140100012). The work forms part of the activities of the Centre for Offshore Foundation Systems (COFS), established in 1997 under the Australian Research Council's Special Research Centres Program, and supported as a node of the Australian Research Council's Centre of Excellence for Geotechnical Science and Engineering (CE110001009).

\section{REFERENCES}

Achmus, M., Kuo, Y.-S., Abdel-Rahman, K., 2010. Numerical investigation of scour effect on lateral resistance of windfarm monopiles. In: Proc of The Twentieth International Offshore and Polar Engineering Conference. ISOPE, Beijing, China, pp. 619-623.

Alderlieste, E., Romp, R., Kay, S., Lofterød, A., 2016. Assessment of Seafloor Trench for Suction Pile Moorings: a Field Case. In: Proc of Offshore Technology Conference. OTC, Houston, Texas, OTC-27035-MS.

Andersen, K., Murff, J., Randolph, M., Clukey, E., Erbrich, C., Jostad, H., Hansen, B., Aubeny, C., Sharma, P., Supachawarote, C., 2005. Suction anchors for deepwater applications. In: Proc of the $1^{\text {st }}$ International Symposium on Frontiers in Offshore Geotechnics (ISFOG 2005), Perth, Australia, pp. 3-30. 
Andersen, K.H., Dyvik, R., Schrøder, K., Hansteen, O.E., Bysveen, S., 1993. Field tests of anchors in clay II: predictions and interpretation. Journal of Geotechnical Engineering 119 (10), 1532-1549.

Andersen, K.H., Jostad, H.P., 1999. Foundation design of skirted foundations and anchors in clay. In: Proc of Offshore Technology Conference. OTC, Houston, Texas, OTC-10824-MS. Arslan, H., Peterman, B.R., Wong, P.C., Bhattacharjee, S., 2015. Remaining Capacity of the Suction Pile due to Seabed Trenching. In: Proc of the $20^{\text {th }}$ International Offshore and Polar Engineering Conference. ISOPE, Hawaii, USA, pp. 924-931.

Aubeny, C., Han, S., Murff, J., 2003. Inclined load capacity of suction caissons. International Journal for Numerical and Analytical Methods in Geomechanics 27 (14), 1235-1254.

Bhattacharjee, S., Majhi, S.M., Smith, D., Garrity, R., 2014. Serpentina FPSO Mooring Integrity Issues and System Replacement: Unique Fast Track Approach. In: Proc of Offshore Technology Conference. OTC, Houston, Texas, OTC-25449-MS.

Brezzi, F., Fortin, M., 2012. Mixed and hybrid finite element methods. Springer-Verlag New York, New York.

Bridge, C.D., Howells, H.A., 2007. Observations and modeling of steel catenary riser trenches. In: Proc of the $7^{\text {th }}$ International Offshore and Polar Engineering Conference. ISOPE, Lisbon, Portugal, pp. 803-813.

Clukey, E.C., Aubeny, C.P., Murff, J.D., 2003. Comparison of analytical and centrifuge model tests for suction caissons subjected to combined loads. In: Proc of the $22^{\text {nd }}$ International Conference on Offshore Mechanics and Arctic Engineering. American Society of Mechanical Engineers, pp. 889-894.

Colliat, J.-L., Safinus, S., Boylan, N., Schroeder, K., 2018. Formation and Development of Seabed Trenching from Subsea Inspection Data of Deepwater Gulf of Guinea Moorings. In: Proc of Offshore Technology Conference. OTC, Houston, Texas, OTC-29034-MS.

Colliat, J., Dendani, H., Puech, A., Nauroy, J., 2010. Gulf of Guinea deepwater sediments: Geotechnical properties, design issues and installation experiences. In: Proc of the $2^{\text {nd }}$ International Symposium on Frontiers in Offshore Geotechnics (ISFOG 2010), Perth, Australia, pp. 59-86.

Ehlers, C., Chen, J., Roberts, H., Lee, Y., 2005. The origin of near-seafloor crust zones in deepwater. In: Proc of the $1^{\text {st }}$ Int. Symp. on Front. in Offshore Geotech. (ISFOG 2005). Taylor and Francis, Perth, Australia, pp. 927-934.

Erbrich, C., Hefer, P., 2002. Installation of the Laminaria Suction Piles - A Case History. In: Proc of Offshore Technology Conference. Offshore Technology Conference, Houston, Texas, OTC-14240-MS.

Gibson, R.E., Morgenstern, N., 1962. A Note on the Stability of Cuttings in Normally Consolidated Clays. Géotechnique 12 (3), 212-216.

$\mathrm{Hu}$, Y., Randolph, M.F., 2002. Bearing capacity of caisson foundations on normally consolidated clay. Soils and Foundations 42 (5), 71-77.

ISO, 2016. Petroleum and natural gas industries specific requirements for Offshore Structures

- Part 4: Geotechnical and foundation design considerations - $2^{\text {nd }}$ Eidition. International Organization for Standardization, Geneva.

Kuo, M., Bolton, M., 2013. The nature and origin of deep ocean clay crust from the Gulf of Guinea. Géotechnique 63 (6), 500-509.

Martin, C.M., Randolph, M.F., 2006. Upper-bound analysis of lateral pile capacity in cohesive soil. Géotechnique 56 (2), 141-145.

Murff, J.D., Hamilton, J.M., 1993. P-ultimate for undrained analysis of laterally loaded piles. Journal of Geotechnical Engineering 119 (1), 91-107.

O'Neill, M., Erbrich, C., McNamara, A., 2018. Prediction of Seabed Trench Formation Induced by Anchor Chain Motions. In: Proc of Offshore Technology Conference. OTC, Houston, Texas, OTC-29068-MS. 
601

602

603

604

605

606

607

608

609

610

611

612

613

614

615

616

Oh, K.-Y., Nam, W., Ryu, M.S., Kim, J.-Y., Epureanu, B.I., 2018. A review of foundations of offshore wind energy convertors: Current status and future perspectives. Renewable and Sustainable Energy Reviews 88, 16-36.

Qi, W.G., Gao, F.P., Randolph, M.F., Lehane, B.M., 2016. Scour effects on p-y curves for shallowly embedded piles in sand. Géotechnique 66 (8), 648-660.

Quirós, G.W., Little, R.L., Garmon, S., 2000. A Normalized Soil Parameter Procedure for Evaluating In-Situ Undrained Shear Strength. In: Proc of Offshore Technology Conference. Offshore Technology Conference, Houston, Texas, OTC-12090-MS.

Randolph, M., House, A., 2002. Analysis of suction caisson capacity in clay. In: Proc of Offshore Technology Conference. OTC, Houston, Texas, OTC-14236-MS.

Sassi, K., Kuo, M., Versteele, H., Cathie, D., Zehzouh, S., 2017. Insights into the Mechanisms of Anchor Chain Trench Formation. In: Proc of the $8^{\text {th }}$ Offshore Site Investigations and Geotechnics Conference, Society for Underwater Technology (OSIG 2017). Society of Underwater Technology, London, UK, pp. 10-12.

Saviano, A., Pisanò, F., 2017. Effects of misalignment on the undrained HV capacity of suction anchors in clay. Ocean Engineering 133, 89-106.

Senders, M., Kay, S., 2002. Geotechnical suction pile anchor design in deep water soft clays. In: Proc of the $7^{\text {th }}$ IBC Deepwater Risers, Moorings and Anchorings Conference. IBC, London, UK, p. 50.

Statoil, 2015. Hywind Scotland Park. https://www.statoil.com/content/dam/statoil/documents/impact-assessment/Hywind/StatoilEnvironmental Statement April 2015.pdf.

Steensen-Bach, J., 1992. Recent model tests with suction piles in clay and sand. In: Proc of Offshore Technology Conference. OTC, Houston, Texas, OTC-6844-MS.

Supachawarote, C., Randolph, M., Gourvenec, S., 2004. Inclined pull-out capacity of suction caissons. In: Proc of the $14^{\text {th }}$ International Offshore and Polar Engineering Conference. ISOPE, Toulon, France, pp. 500-506.

Supachawarote, C., Randolph, M., Gourvenec, S., 2005. The effect of crack formation on the inclined pull-out capacity of suction caissons. In: Proc of International Association for Computer Methods and Advances in Geomechanics (IACMAG), Turin, Italy, pp. 19-24.

Tjelta, T., 2015. The suction foundation technology. In: Proc of the $3^{\text {rd }}$ International Symposium on Frontiers in Offshore Geotechnics, Oslo, Norway, pp. 85-93.

Watson, P., Randolph, M., 1997. Vertical capacity of caisson foundations in calcareous sediments. In: Proc of the $7^{\text {th }}$ International Offshore and Polar Engineering Conference. ISOPE, Honolulu, USA, pp. 784-790.

Watson, P., Randolph, M., Bransby, M., 2000. Combined lateral and vertical loading of caisson foundations. In: Proc of Offshore Technology Conference. Offshore Technology Conference, Houston, Texas, OTC-12195-MS.

Zdravkovic, L., Potts, D., Jardine, R., 2001. A parametric study of the pull-out capacity of bucket foundations in soft clay. Géotechnique 51 (1), 55-67. 
TABLE

618 Table 1 Comparison of the geotechnical capacity of caisson in intact and trenching seabed for 619 the example application

\begin{tabular}{|l|l|l|l|}
\hline \multirow{2}{*}{ Trench wdith, w/D } & \multicolumn{2}{|c|}{ Normalised horizontal capacity factor, $\mathrm{N}_{\mathrm{h}}$} & \\
\hline Intact & UTI & ZTI (2) & {$[(1)-(2)] /(1)_{\text {intact }}$} \\
\hline$\rightarrow 0$ & 10.89 & 7.48 & 0.313 \\
\hline 0.25 & 9.75 & 6.37 & 0.310 \\
\hline 0.50 & 9.15 & 5.78 & 0.309 \\
\hline 0.75 & 8.51 & 5.14 & 0.310 \\
\hline 1.00 & 7.90 & 4.49 & 0.313 \\
\hline
\end{tabular}

620

621 


\section{FIGURE CAPTIONS}

623 Figure 1 Mooring line and anchorage arrangements for catenary and taut moorings

624 Figure 2 Schematic of seabed trenching around a taut-line mooring (based on case study in

625 Bhattacharya et al. 2014)

626 Figure 3 Nomenclature for problem definition

627 Figure 4 Example of FE mesh for suction caissons in trenched seabed $(w / D=0.75)$

628 Figure 5 Failure mechanism assumed for a horizontally translating caisson and profile of unit

629 lateral resistance

630 Figure 6 Reduction in the pullout and translational capacity of suction caissons with varying 631 trench width

632 Figure 7 End bearing capacity factor and horizontal capacity factor for suction caissons in 633 intact and trenched seabed

634 Figure 8 Soil flow mechanisms around translating caissons with UTI (Contours of soil 635 movement relative to caisson displacement)

636 Figure 9 Soil flow mechanisms around translating caissons with ZTI (Contours of soil 637 movement relative to caisson displacement)

638 Figure 10 Components of reduction in load capacity of caissons in trenched seabed with load 639 attachment point at optimal depth for intact seabed

640 Figure 11 Depth to optimal load intersection with the centreline for suction caissons in 641 trenched seabed for varying padeye positions

642 Figure 12 Example showing dependence of geotechnical capacity on the depth to load 643 intersection point at the centreline and load inclination angle (UTI; w/D $=0.25$ )

644 Figure 13 Comparison of $\mathrm{V}-\mathrm{H}$ failure envelopes for suction caissons in intact and trenched 645 seabed

646 Figure 14 Normalised V-H failure envelopes for suction caissons in intact and trenched 647 seabed

648 Figure 15 Loading diagram for a translating caisson in trenched seabed

649 Figure 16 Effect of padeye offset on the load capacity of the suction caisson if designing for 650 inevitable trenching

651 Figure 17 Effect of seabed trenching and gapping conditions on the inclined capacity for the 652 example application based on Bhattacharjee et al. (2014) 
654
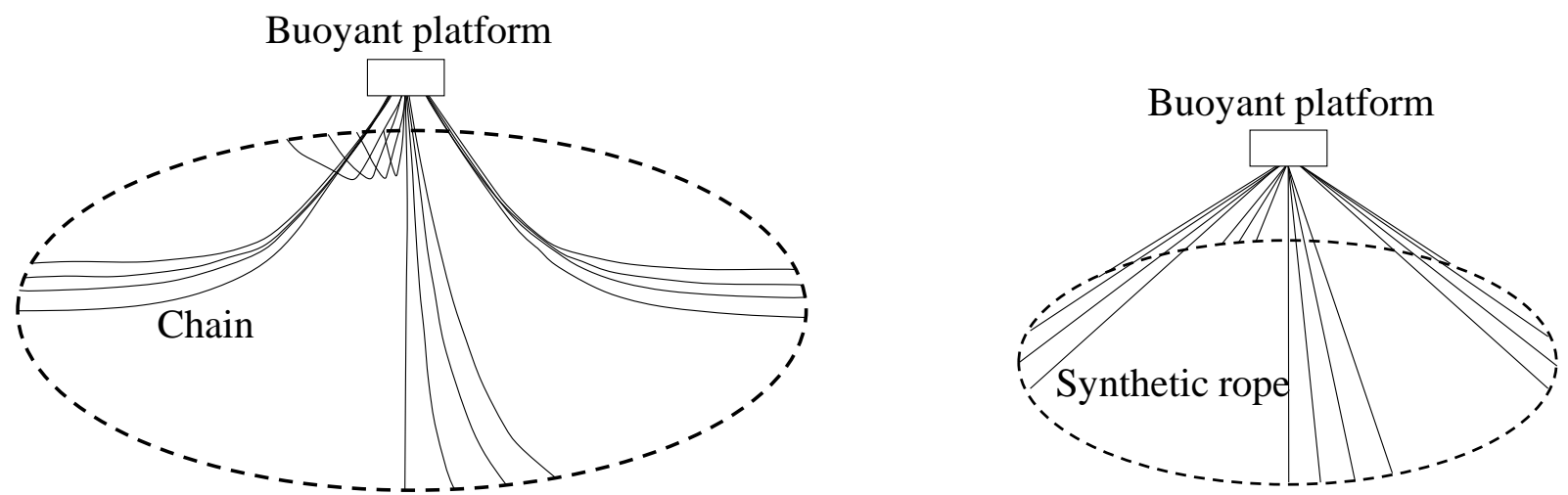

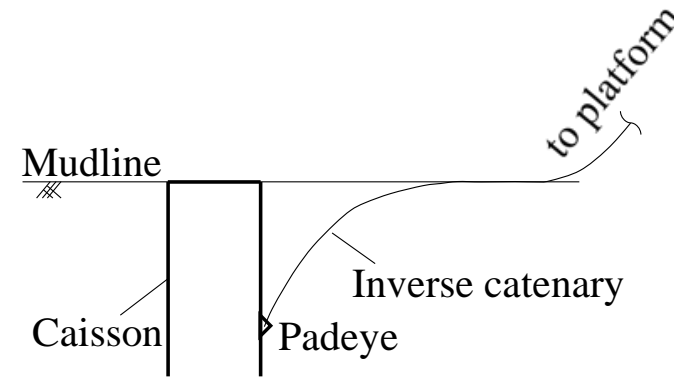

a) Catenary mooring

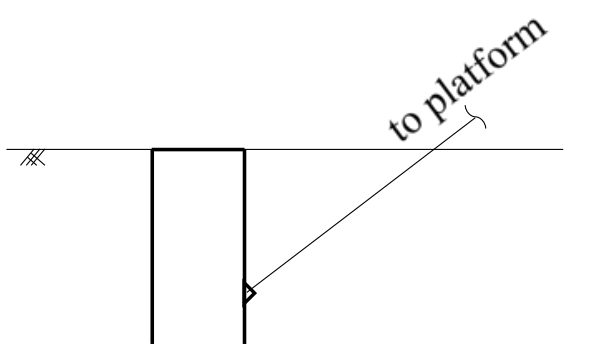

b) Taut mooring
655

Figure 1 Mooring line and anchorage arrangements for catenary and taut moorings

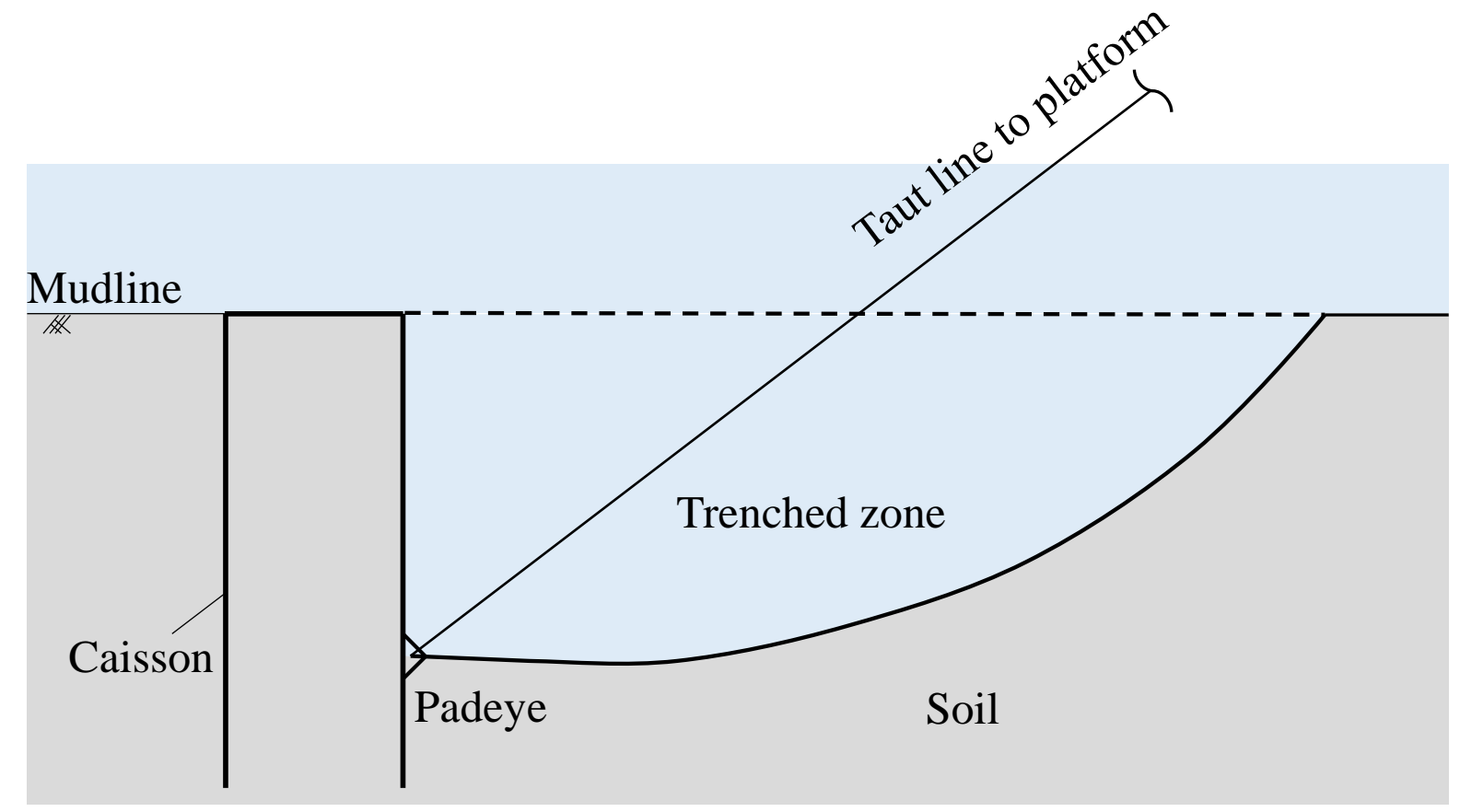

Figure 2 Schematic of seabed trenching around a taut-line mooring (based on Bhattacharjee et al. 2014 case study) 

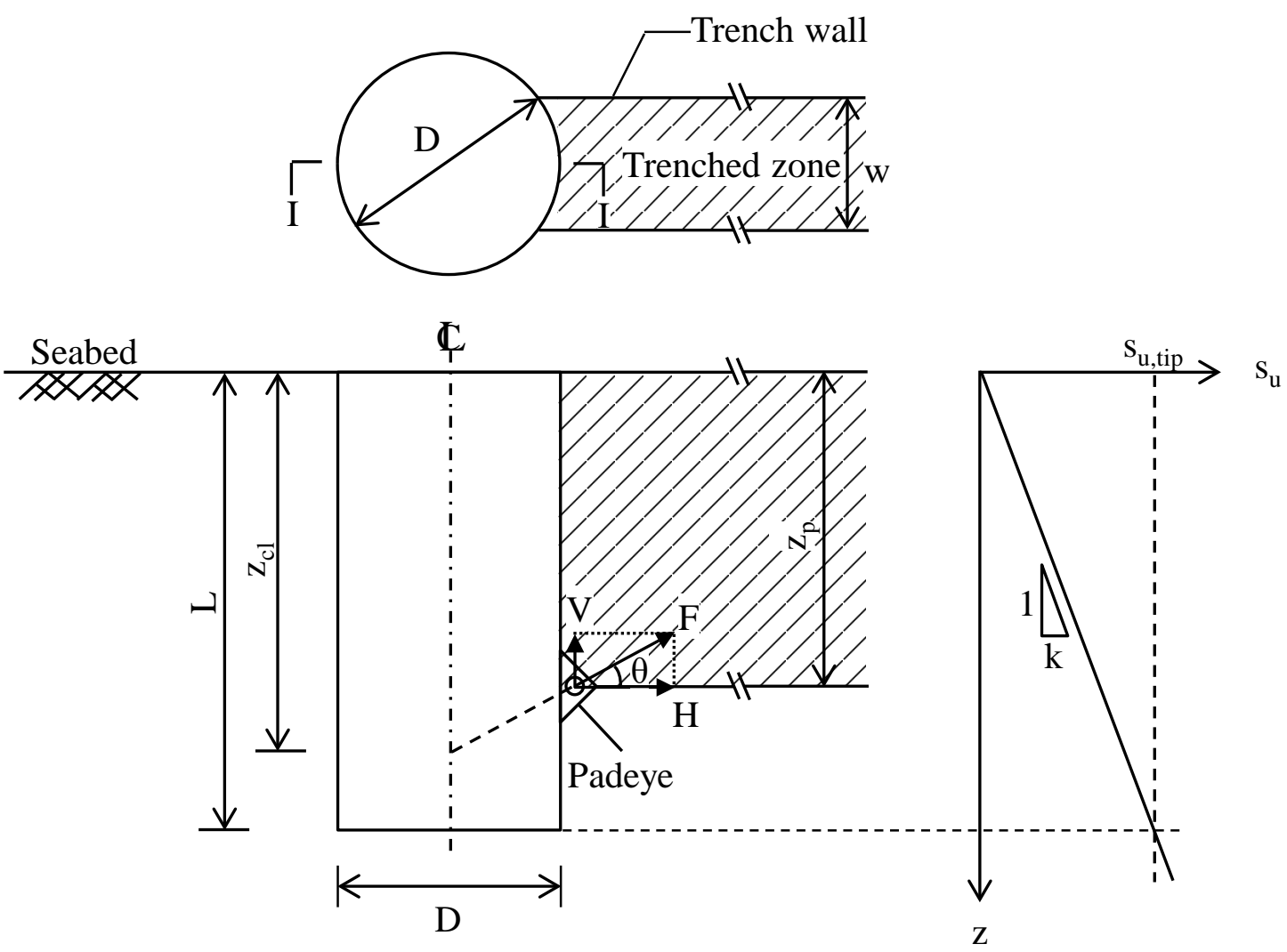

665

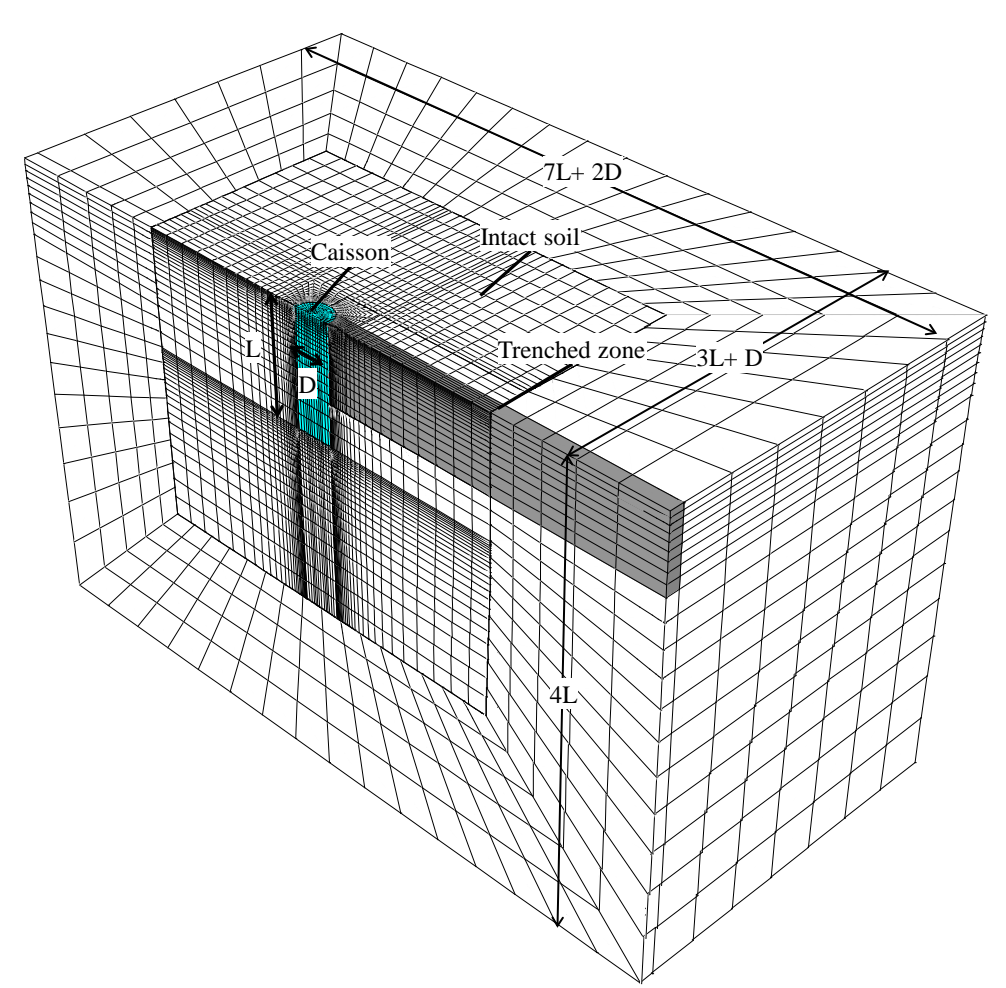

Figure 3 Nomenclature for problem definition

\section{I - I Plane of Symmetry}

Figure 4 Example of FE mesh for suction caissons in trenched seabed $(\mathrm{w} / \mathrm{D}=0.75)$ 
670

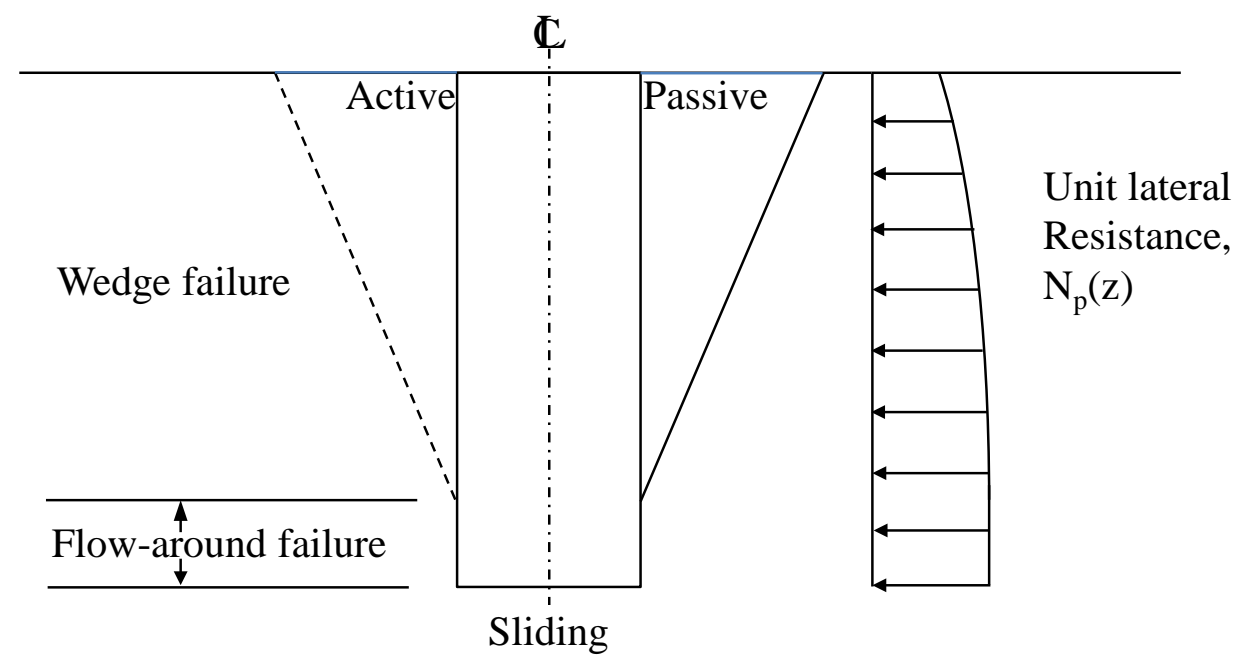

671

672

673

674

Figure 5 Failure mechanism assumed for a horizontally translating caisson and profile of unit lateral resistance

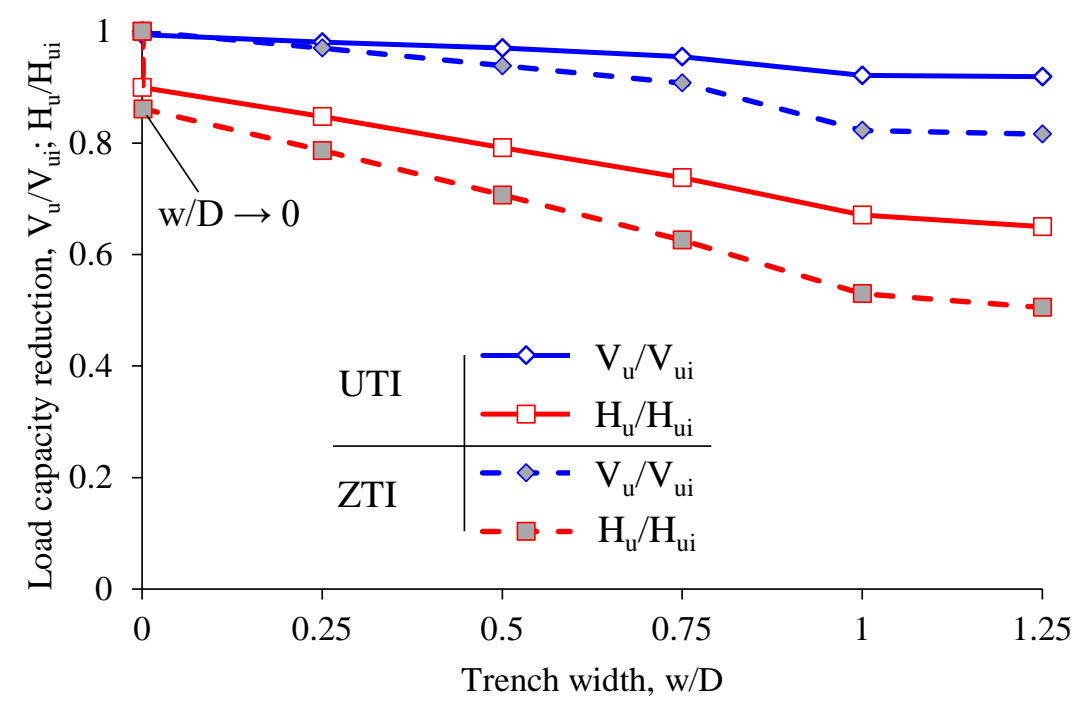

675

676

677

678
Figure 6 Reduction in the pullout and translational capacity of suction caissons with varying trench width 
679

680

681

682

683

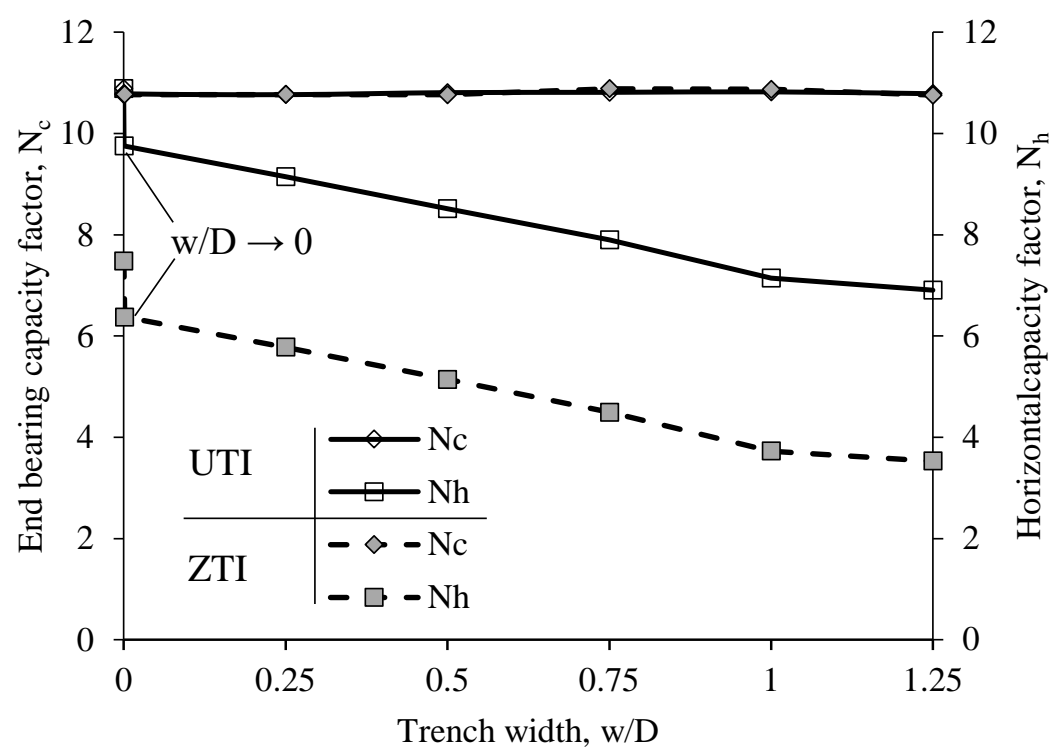

Figure 7 End bearing capacity factor and horizontal capacity factor for suction caissons in intact and trenched seabed

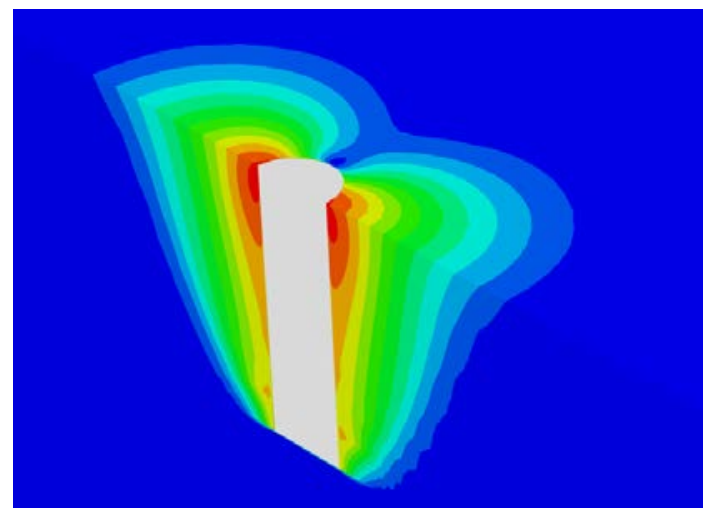

a) Intact seabed, w/D $=0$

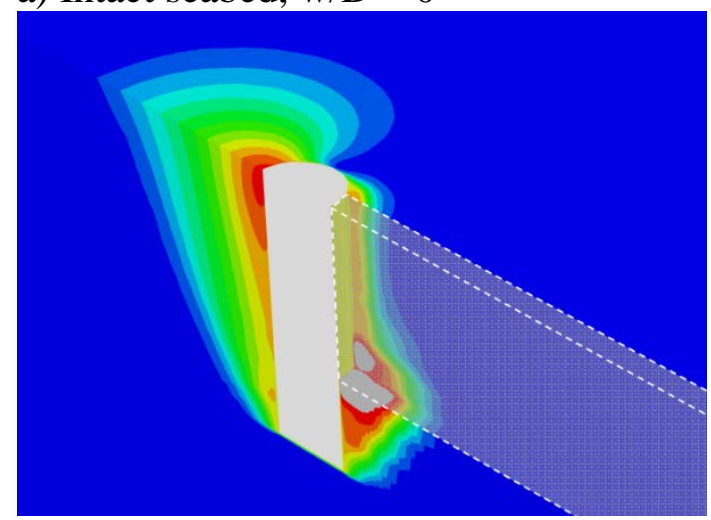

c) Trench seabed, w/D = 0.5

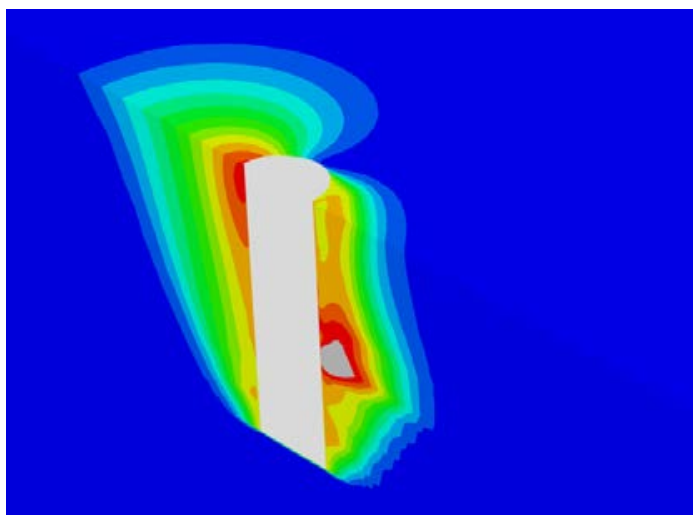

b) Trench seabed, w/D $\rightarrow 0$

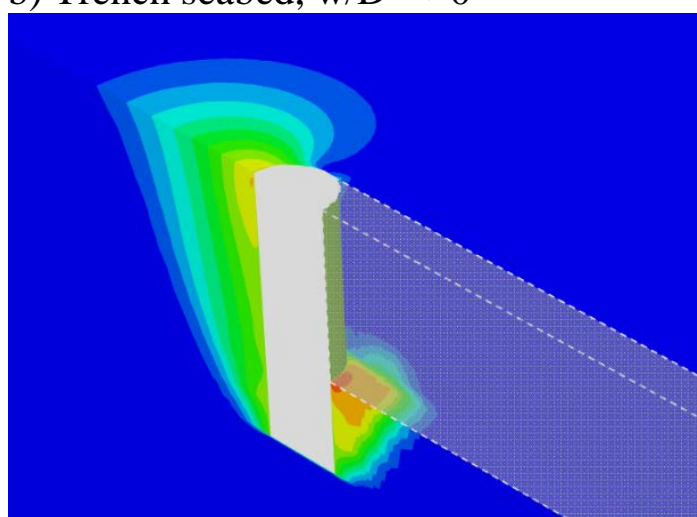

d) Trench seabed, w/D = 1.0

685 Figure 8 Soil flow mechanisms around translating caissons with UTI (Contours of soil movement relative to caisson displacement) 


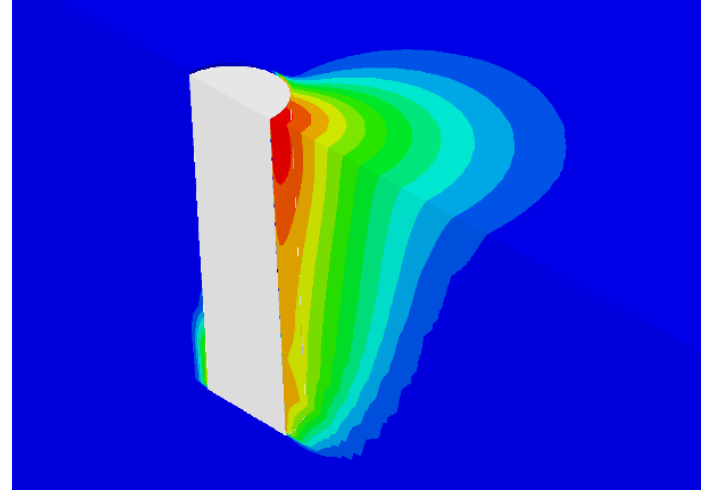

a) Intact seabed, w/D $=0$

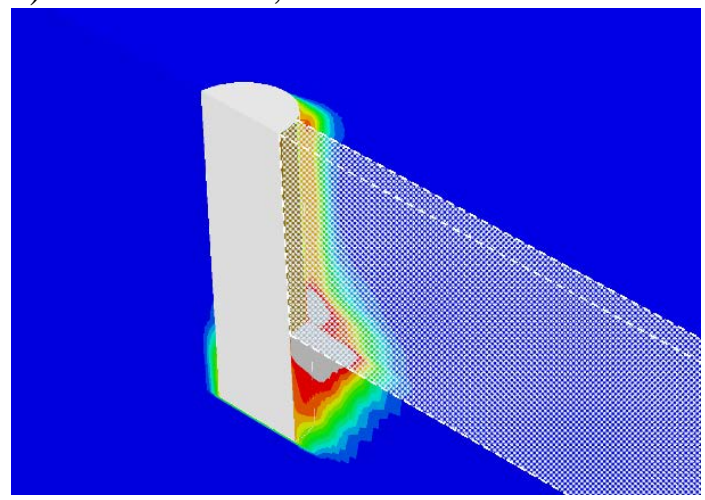

c) Trench seabed, w/D $=0.5$

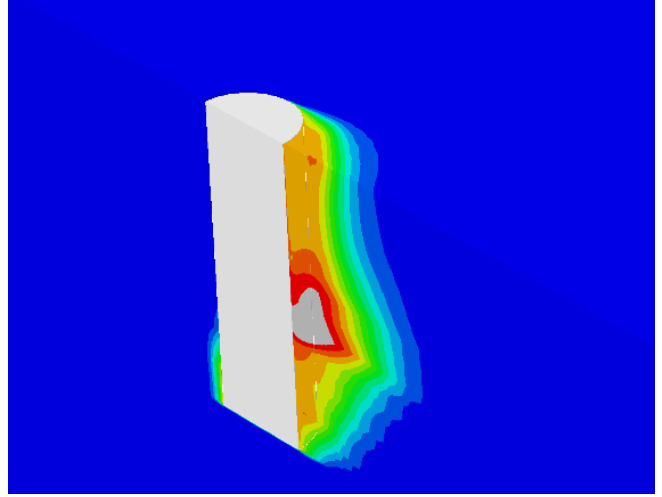

b) Trench seabed, w/D $\rightarrow 0$

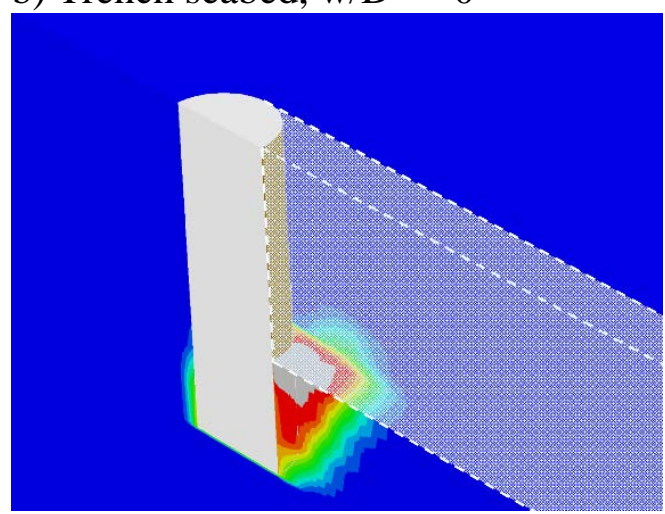

d) Trench seabed, w/D = 1.0

689 Figure 9 Soil flow mechanisms around translating caissons with ZTI (Contours of soil 690 movement relative to caisson displacement)

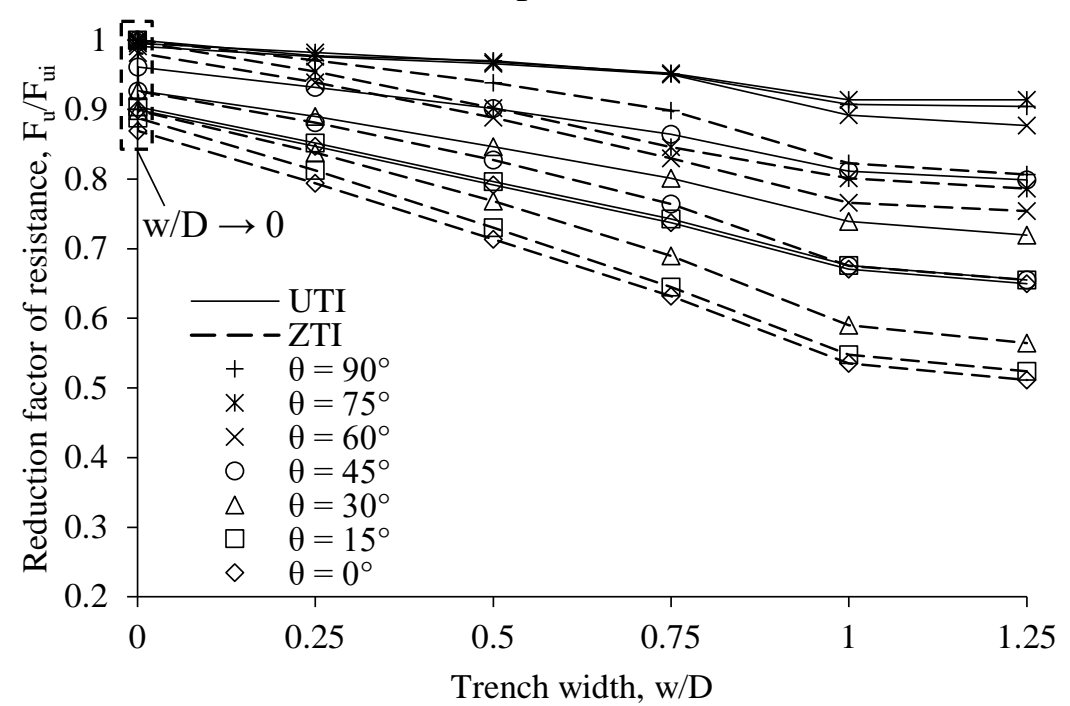

691

692 a) effect of loss of soil support and suction 


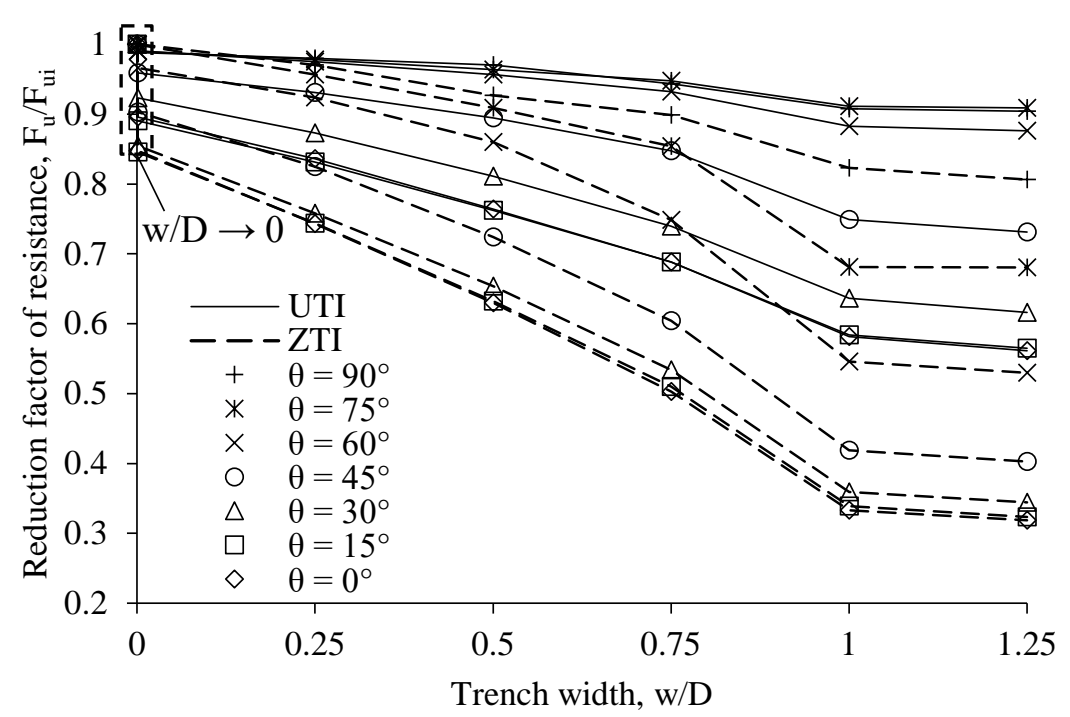

693

b) effect of rotation

695

696

697

698

Figure 10 Components of reduction in load capacity of caissons in trenched seabed with load attachment point at optimal depth for intact seabed

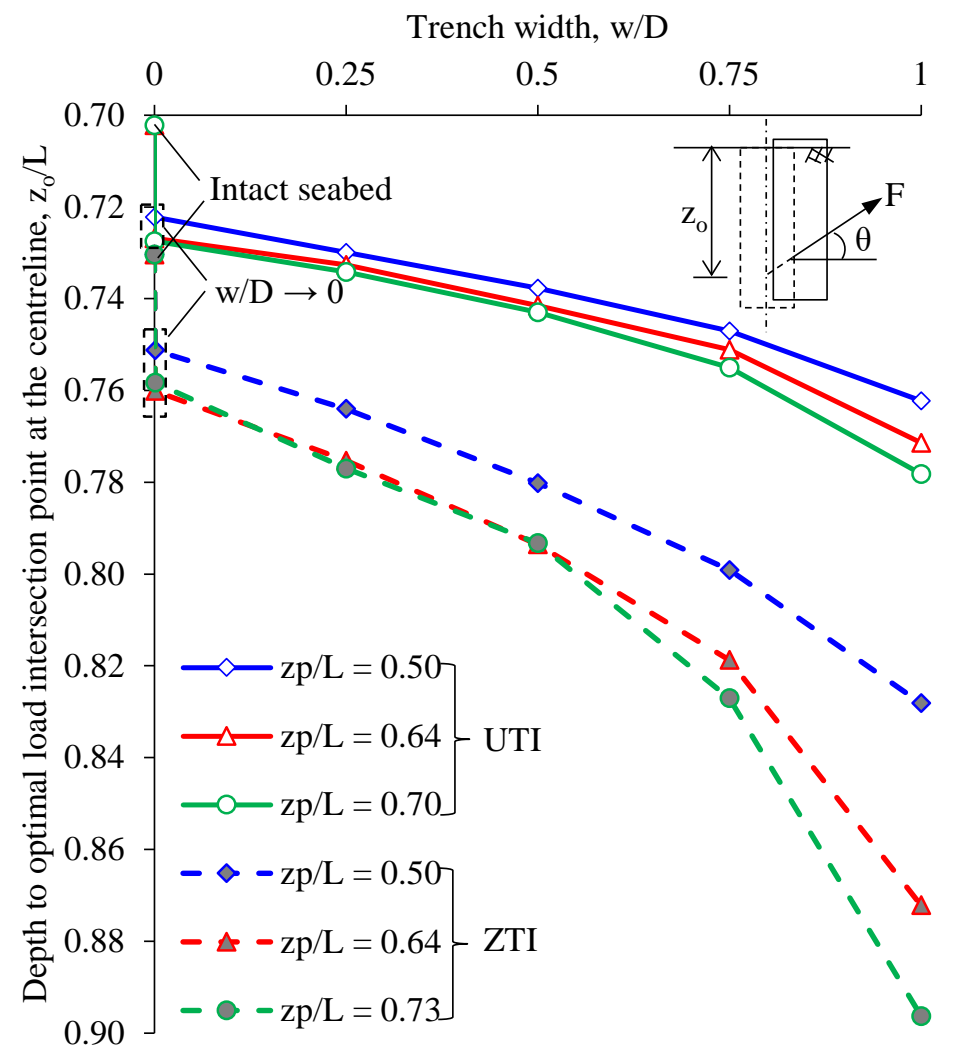

Figure 11 Depth to optimal load intersection with the centreline for suction caissons in trenched 


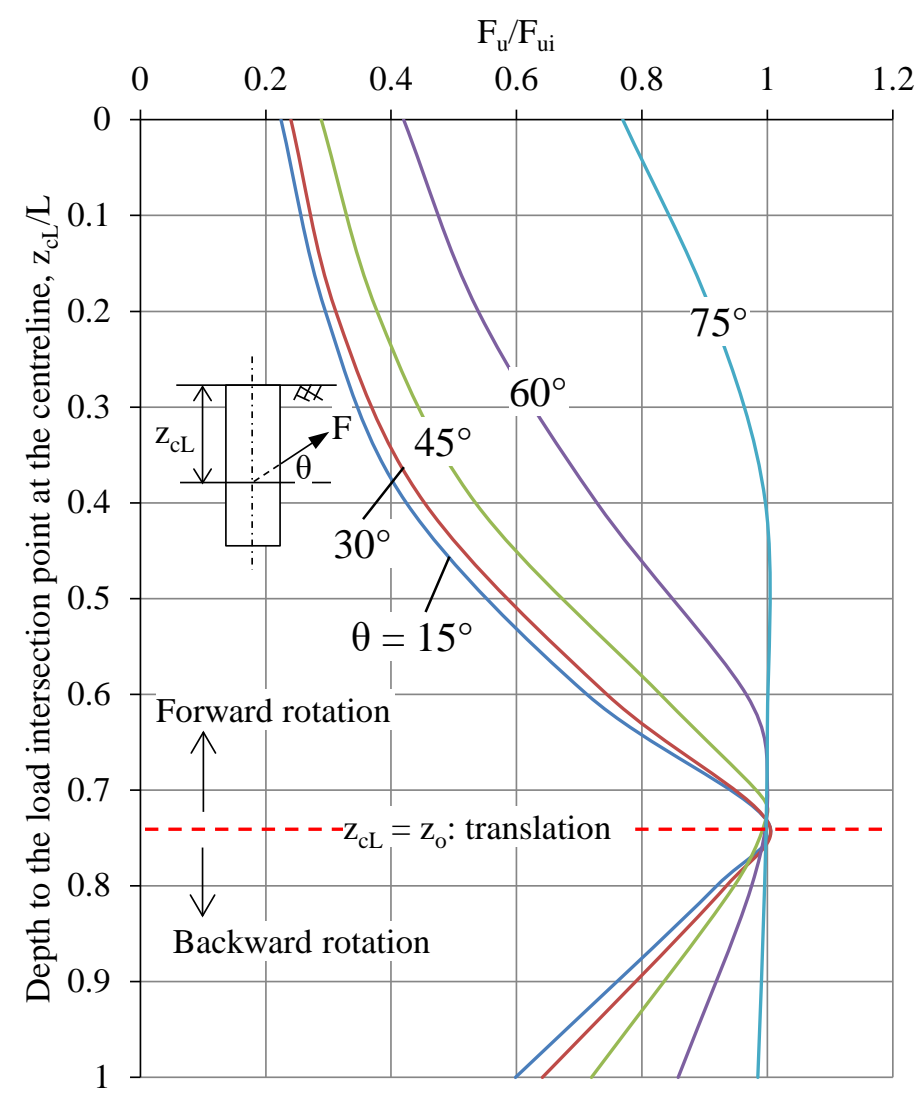

Figure 12 Example showing dependence of geotechnical capacity on the depth to load intersection point at the centreline and load inclination angle

708

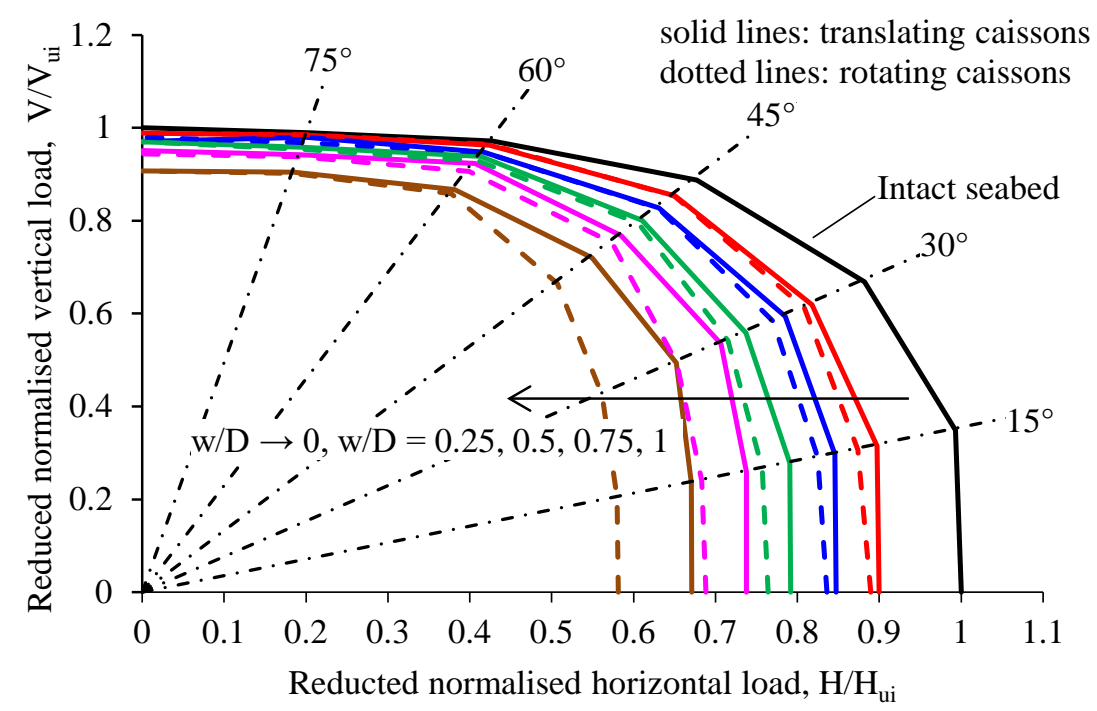

a) unlimited tension interface 


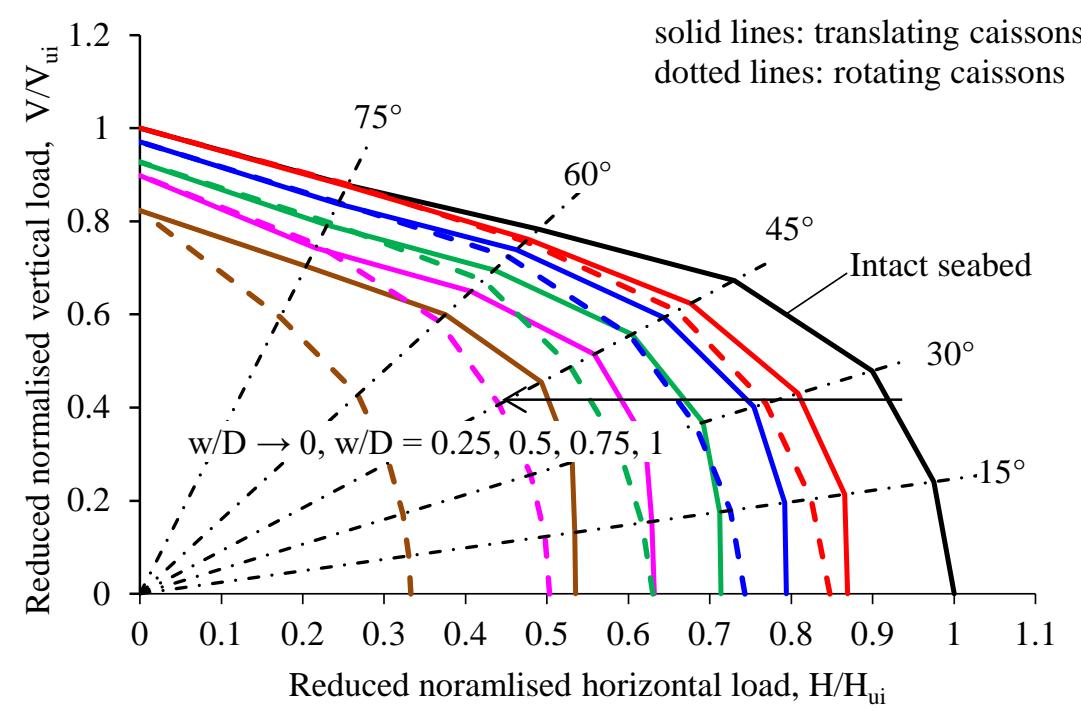

712

b) zero-tension interface

Figure 13 Comparison of V-H failure envelopes for suction caissons in intact and trenched seabed

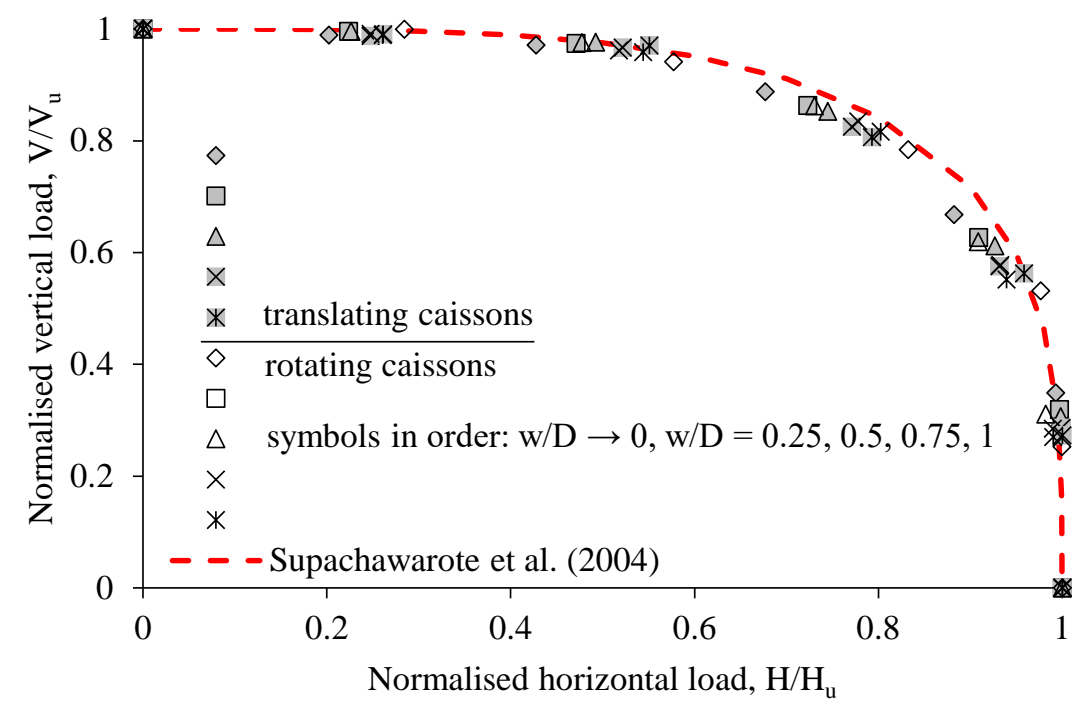

a) unlimited tension interface 


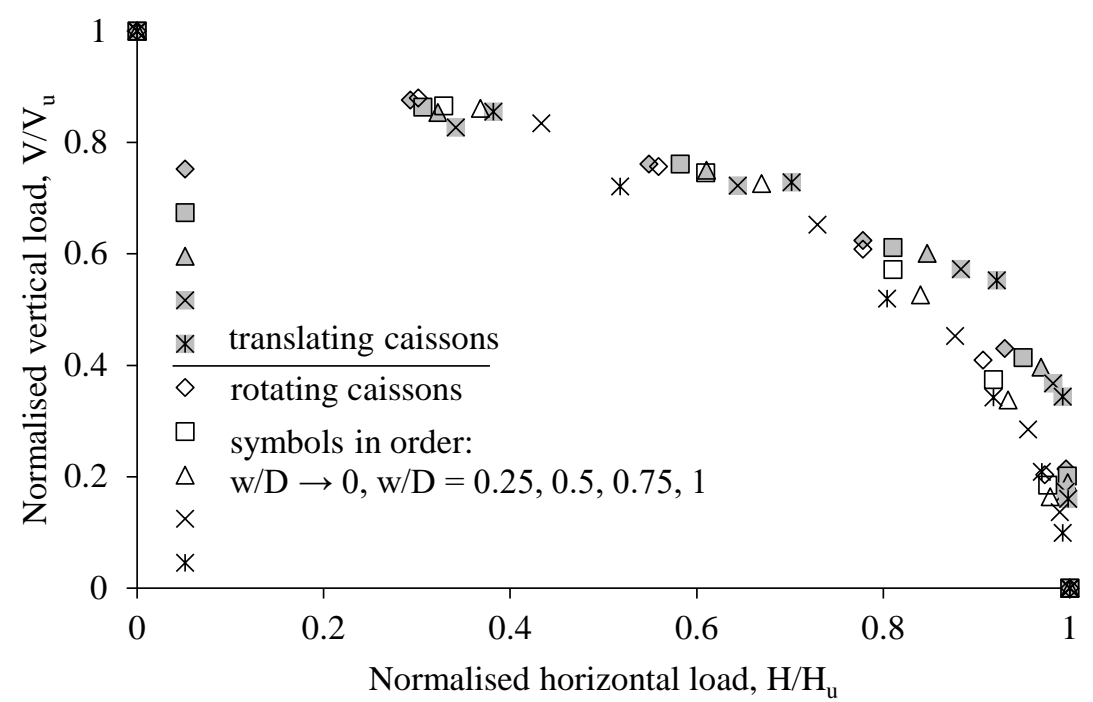

721

b) zero-tension interface

Figure 14 Normalised V-H failure envelopes for suction caissons in intact and trenched seabed

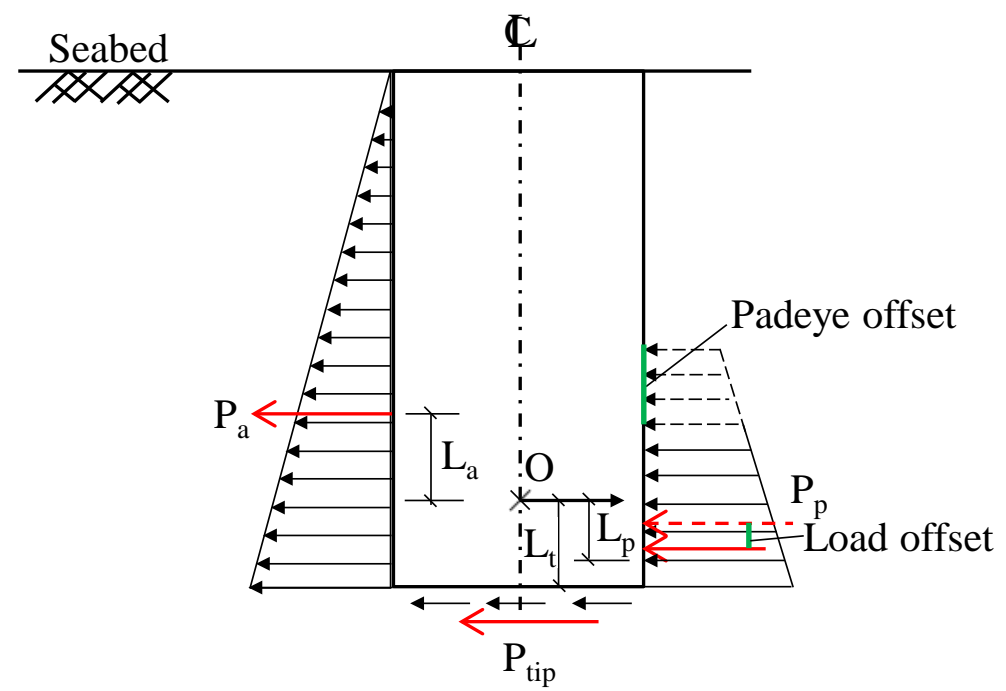

Figure 15 Loading diagram for a translating caisson in trenched seabed 


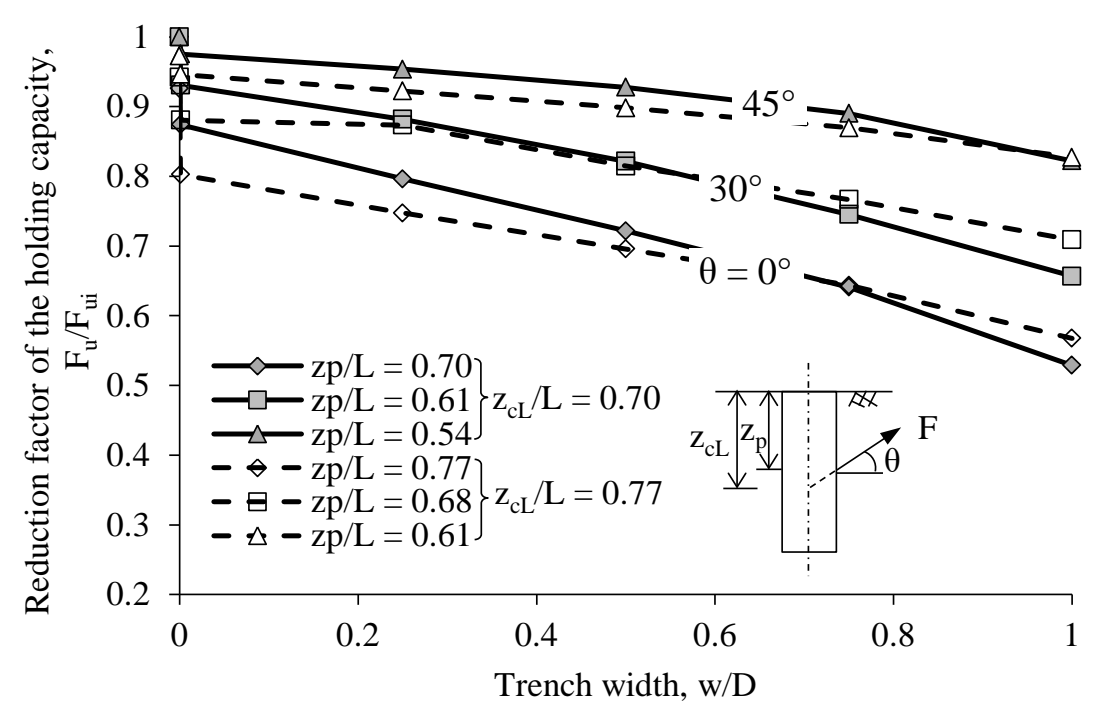

a) $\theta \leq 45^{\circ}$; unlimited tension interface

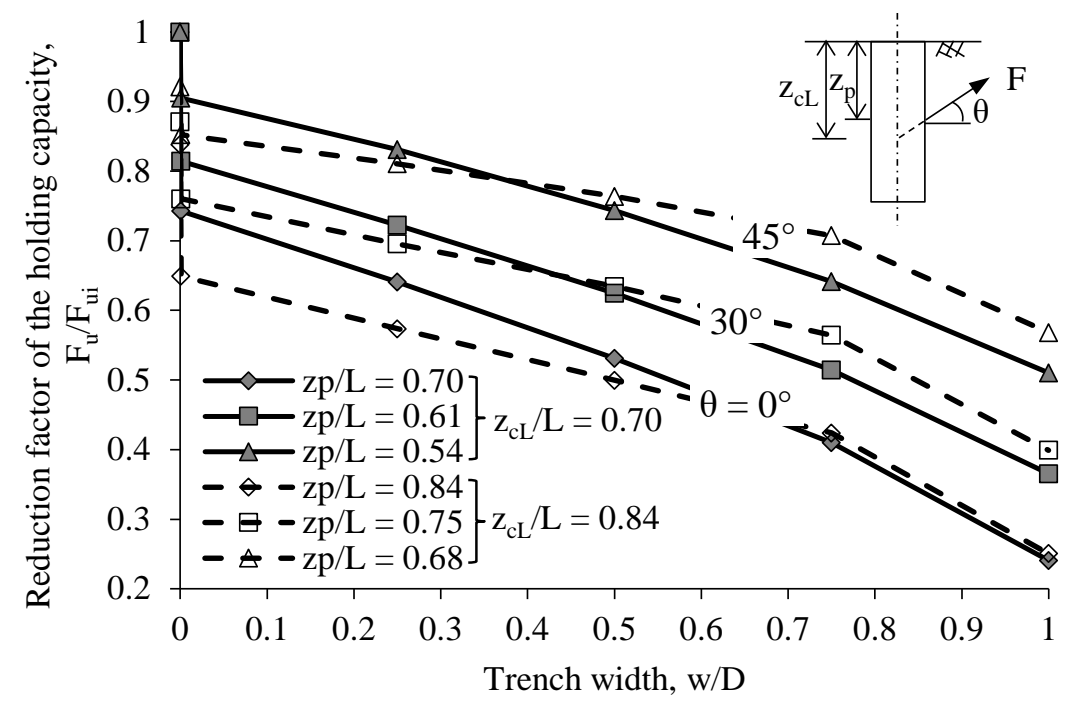

b) $\theta \leq 45^{\circ}$; zero-tension interface

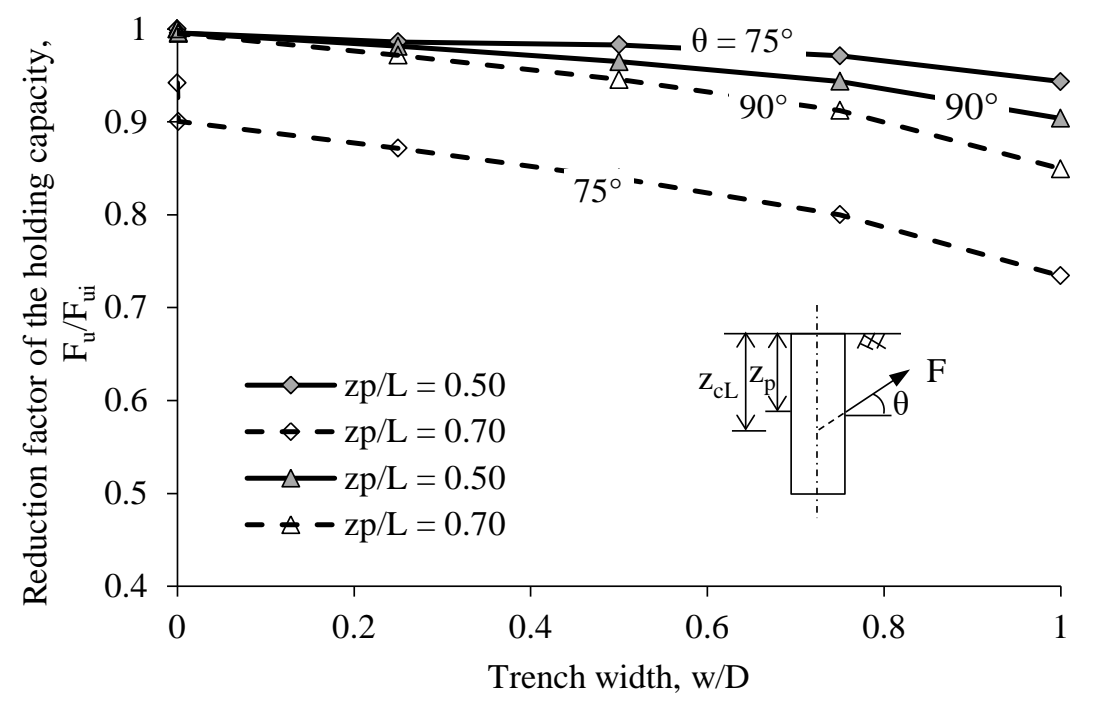


c) $\theta \geq 75^{\circ}$; unlimited tension interface

Figure 16 Effect of padeye offset on the load capacity of the suction caisson

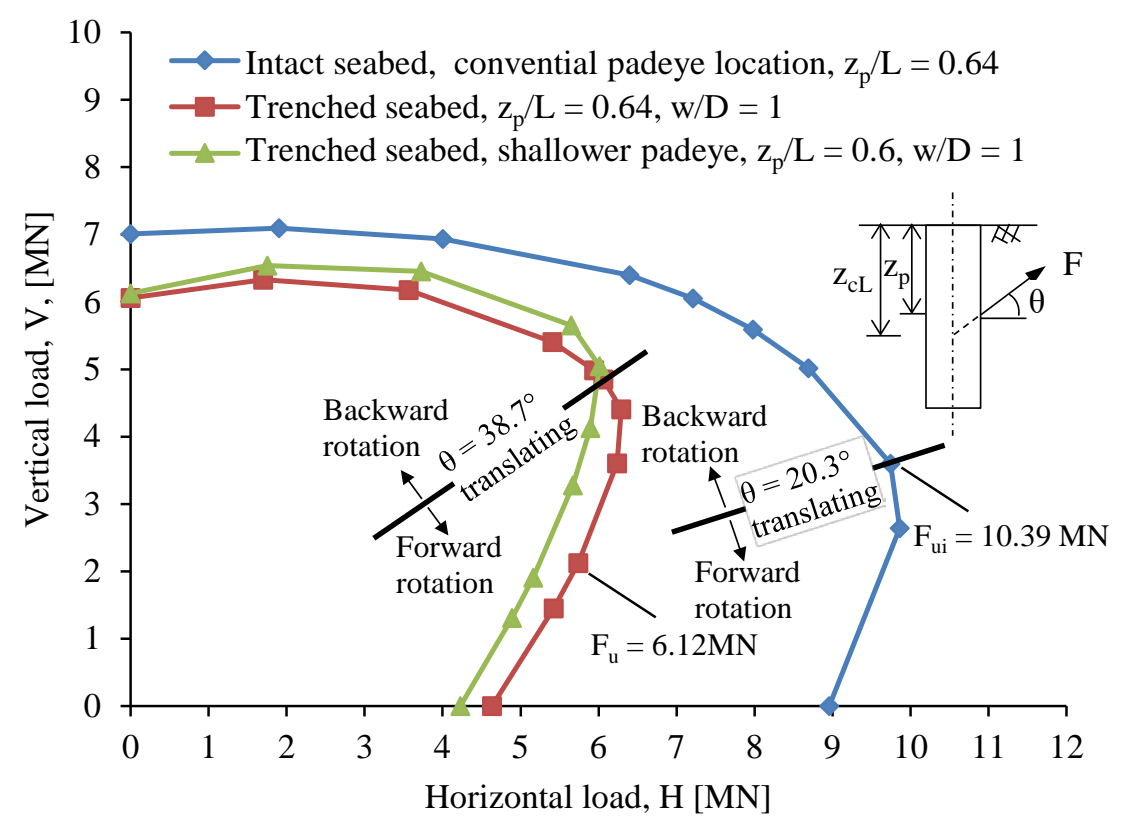

a) unlimited tension interface

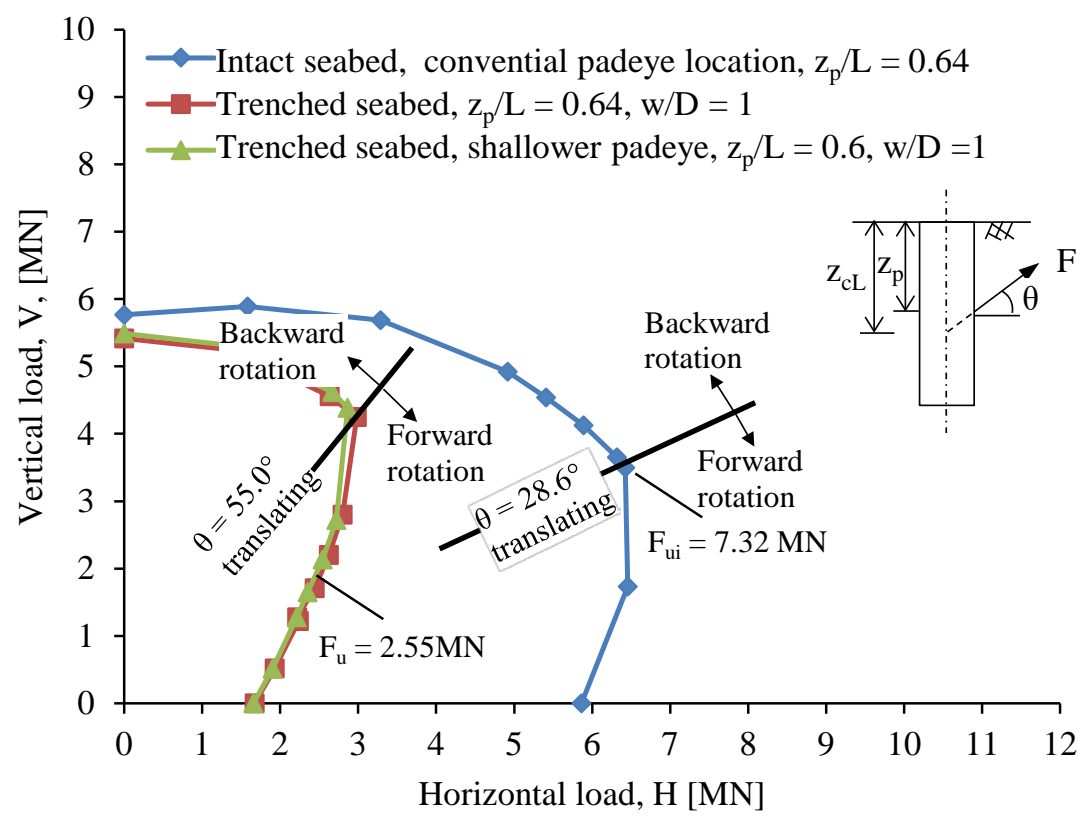

b) zero-tension interface

Figure 17 Effect of seabed trenching and gapping conditions on the inclined capacity for the 